\title{
Arabuluculuk ve Tahkimi Bir Arada İçeren Uyuşmazlık Çözüm Yolu
}

\author{
Cemile Demir Gökyayla* (1)
}

Öz

Çok basamaklı tahkim anlaşmalarında, tarafların, öncelikle arabulucuya başvuracakları ve uyuşmazlığın arabuluculuk yoluyla çözümlenememesi hâlinde tahkime başvurulabilecekleri kararlaştrılmaktadır (Arabuluculuk - Tahkim Yolu). Çok basamaklı tahkim anlaşmaları, uyuşmazlığın arabuluculuk yoluyla çözümlenememesi hâlinde tahkim yoluyla çözüleceğine dair taraf iradelerini herhangi bir tereddüde yer vermeyecek şekilde yansitabiliyorsa geçerlidir. Taraflardan birisinin arabuluculuk yoluna hiç başvurmadan ya da süreç devam ederken tahkim yoluna başvurması hâlinde, hakemler öncelikle arabuluculuk yoluna başvurulmasının tahkim yoluna başvurulabilmenin bir ön koşulu olup olmadığını incelemelidir. Arabuluculuk bir ön koşulsa yargılamayı durdurup tarafların arabuluculuk aşamasına başvurmalarına ve arabuluculuk başarıı olmazsa tahkime devam edilmesine karar vermeleri gerekir. Arabulucunun hakem olarak da görev almasının isabetli olup olmadığı tartışmalıdır zira arabulucunun tahkim yargılamasında hakem olarak görev almasının önemli sakıncaları vardır. Amerika, Avrupa ve Türkiye'de benimsenen arabuluculuk ve tahkimle ilgili etik kurallara göre arabulucu ancak tarafların yazııı olarak muvafakat vermeleri hâlinde hakem olarak görev yapabilir. Bu hâlde bile, gizli bilgi ve belgelerin paylaşılması ve hakemin arabulucu olarak geliştirdiği önyargıları olması ihtimali vardır.

Bir diğer husus da arabuluculuk aşamasında teati edilen bilgi ve belgelerin tahkim aşamasında delil olarak kullanılmasının hukuka uygun olup olmayacă̆ı konusudur. Bu konuda arabuluculuk süreci nedeniyle ve bu sürece özgü olarak hazırlanan belgeler ve vakıaları ispata yarayan belgeler arasında ayrım yapılmaktadır.

\section{Anahtar Kelimeler}

Tahkim, Hakem, Arabulucui Hakem kararlarının iptali, Delillerin kabul edilebilirliği

\section{Multi-Tier Dispute Resolution Clauses Incorporating Both Mediation and Arbitration Together Under Turkish Law}

\section{Abstract}

Parties may agree that in the case of a dispute they shall first try to settle this dispute through mediation and only if the mediation fails may they start arbitration proceedings. Under Turkish law, such multi-tier dispute resolution clauses are valid to the extent that the parties' intention to resort to arbitration is clear. In the case where one of the parties starts the arbitration without first invoking the mediation, the arbitral tribunal should interpret the arbitration agreement to determine whether the mediation is a pre-condition of arbitration. If the mediation is a pre-condition, the tribunal should suspend the arbitral proceeding for the parties to invoke the mediation. However, if the mediation fails, then the tribunal will resume the proceedings. The question of whether or not the mediator should also act as the arbitrator in relation to the same dispute is highly debatable because of the risks imminent thereto. Under the ethics rules accepted in the USA, in Europe and in Turkey, the mediator may act as arbitrator only if the parties agree thereon in written form. When the parties consent to the mediator acting as arbitrator there is still the risk of the mediator-arbitrator having prejudices because of the information and documents disclosed during the mediation proceedings. Another question is whether

\footnotetext{
Sorumlu Yazar: Cemile Demir Gökyayla (Doç. Dr.), İstanbul Bilgi Üniversitesi, Hukuk Fakültesi, Özel Hukuk Bölümü, İstanbul, Türkiye. E-posta: cemile.gokyayla@bilgi.edu.tr ORCID: 0000-0001-6506-9808
}

Atf: Demir Gokyayla C, “Arabuluculuk ve Tahkimi Bir Arada Iç̧eren Uyuşmazlık Çözüm Yolu” (2019) 77(2) i̇stanbul Hukuk Mecmuası 575. https://doi.org/10.26650/mecmua.2019.77.2.0005 
the information or documents disclosed throughout the mediation are admissible evidence at the arbitral proceedings. However, the solution is clear: while the documents prepared for the sole purpose of settling the dispute at the mediation are inadmissible, the documents related to the facts are admissible.

In November 2019, Istanbul Arbitration Center (ISTAC) introduced its own Med-arb rules, namely the ISTAC Med-arb Rules. They are the first published institutional Med-arb rules and reflect the best practices in international mediation - arbitration. I am confident that ISTAC Med-arb Rules will be welcomed in the field of international dispute resolution with great enthusiasm.

\section{Keywords}

Arbitration in Turkey, Mediation in Turkey, Med-Arb, Admissibility of claim, Admissibility of evidence

\section{Extended Summary}

This article deals with multi-tier dispute resolution clauses incorporating both mediation and arbitration together under Turkish Law. I use the terminology of "med-arb" not only for the situation where the mediator acts as an arbitrator, but rather in a general meaning covering all instances where the arbitration is commenced following an unsuccessful mediation.

The purpose of this article is to discuss the validity of the med-arb agreements, the consequences of starting arbitration before the mediation fails, the effects of the mediation proceedings and of the mediator acting as an arbitrator on the arbitration that follows the mediation as well as the admissibility of the documents and factual evidence exchanged at the mediation. For the purpose of this article, the comparative laws, international ethics rules, international guidelines on the conflict of interest and admissibility of evidence are reviewed along with Turkish law.

Turkish Code on Mediation in Civil Law Disputes stipulates some provisions related to the med-arb. These provisions shall apply equally to both domestic and international arbitrations where the place of arbitration is Turkey.

Following the jurisprudence of the Turkish Supreme Court, a med-arb agreement is valid only if it reflects, without doubt, both parties' consents to the arbitration following the failure of the mediation proceedings. Therefore, a multi-tier dispute resolution clause subject to Turkish law needs to be drawn carefully. In this respect IBA Guidelines for Drafting International Arbitration Clauses are of assistance.

In cases where one of the parties commences arbitration without a recourse to mediation first, the arbitral tribunal should make a decision on the admissibility of the claim. There is no direct provision related to the question of admissibility under Turkish law. Under Turkish law, in parallel with the practice of international arbitration, the tribunal has to interpret the med-arb agreement to make a decision on the question of whether the recourse to mediation is a pre-condition of the arbitration. If the mediation is a pre-condition, then the tribunal should suspend the arbitral 
proceedings and direct the parties to the mediation. However, in the case that the mediation fails, the tribunal may resume the arbitral proceedings. There is nothing under Turkish law suggesting that a precondition of arbitration is a jurisdictional issue rather than an admissibility issue.

The advantages of the med-arb are subject to heated debates among people holding different perspectives. Such advantages are controversial since when a dispute arises and the arbitration starts without a recourse to mediation, the respondent may object to the jurisdiction of the tribunal or to the admissibility of the claim relying on the fact that the pre-condition to try mediation first is not met. Such an objection may cause arbitration to be delayed and/or the costs of arbitration to increase. Therefore, before opting for a med-arb agreement the parties should evaluate the possibility of settling their dispute at the Med-arb. The parties who are able to consider their commercial interests do not need a med-arb agreement as they are able to settle the disputes without the assistance of a mediator. They first try to settle the dispute, in some cases for years, and to avoid adjudication by an arbitral tribunal. They only start arbitration when there is no possibility of settlement of their dispute and of saving their commercial alliance. In such cases, med-arb agreements become a tool to delay the proceedings and increase the costs for the claimant to force him or her to give up his or her claim. Having said that, for the parties who are unable to consider their commercial interest and unable to avoid adjudication, med-arb agreement may be the right dispute resolution clause.

In a med-arb agreement, the parties may wish the mediator to act as their arbitrator if the mediation fails. Neither the Turkish Code of Mediation in Civil Disputes nor the Turkish International Arbitration Code prevents a mediator to act as an arbitrator. Turkish Ethics Rules for Mediators stipulate that a mediator may act as an arbitrator only if the parties have agreement in writing. Therefore, any mediator to act as arbitrator needs to have the parties' written consent. In international mediation and arbitration practices, the scholars and practitioners widely accept that having an arbitrator who previously acted as a mediator generates a number of serious risks and concerns. First of all, the mediator-arbitrator may not protect his or her impartiality in the arbitration because of the facts that she or he became aware of during the mediation. Secondly, the mediator-arbitrator may rely on the confidential information exchanged in caucus while making the award. Thirdly, the mediator may be too willing to act as an arbitrator and as a result the mediation may prematurely fail. Finally, the mediator may abuse his or her powers and force the parties to settle their disputes as the mediator suggests. The parties may feel that if they are not able to settle their dispute and proceed to the arbitration, the mediator-arbitrator would make an arbitral award in parallel of the recommendations at the mediation phase. Considering the severity of the consequences, if the parties agree to have an arbitrator 
who previously acted as their mediator, they need to be aware of such consequences and they need to make an informed decision accordingly .

The Turkish Code of Mediation in Civil Law Disputes restrains the ability of the mediator-arbitrator to rely on the documents produced during the mediation for the purpose of settlement and defines which documents are in this category. In the case where the mediator-arbitrator relies on these documents while making the award, depending on the extent the document or information has a bearing on the award, the arbitral award may be cancelled, or its enforcement may be refused.

In November 2019, Istanbul Arbitration Center (ISTAC) introduced its Medarb Rules. ISTAC Med-arb Rules are the first published institutional Med-arb rules. ISTAC Med-arb Rules reflect the best practices in international mediation arbitration. I believe that ISTAC Med-arb Rules will be welcomed in the field of international dispute resolution. 


\section{Arabuluculuk ve Tahkimi Bir Arada İçeren Uyuşmazlık Çözüm Yolu}

\section{Giriş}

Özel hukuka hâkim temel prensiplerden bir tanesi, irade serbestisidir. İrade serbestisi prensibinin sonucu olarak, bireyler, sözleşmelerinin içeriğini (Türk Borçlar Kanunu ("TBK") ${ }^{1}$ madde 26 ve 27), yabancılık unsuru içeren sözleşmelere uygulanacak hukuku (Milletlerarası Özel Hukuk ve Usul Hukuku Hakkında Kanun ("MÖHUK") madde 24), uyuşmazlıkların çözülmesi için yer itibariyle yetkili Türk mahkemelerini veya yabancı mahkemeyi (Hukuk Muhakemeleri Kanunu ("HMK") madde 18 ve MÖHUK.m47) belirleyebilir hatta uyuşmazlıkların Devlet yargısı dışında çözülmesi için tahkim anlaşması yapabilirler (HMK.m406 vd., Milletlerarası Tahkim Kanunu ("MTK") ${ }^{4}$ madde 1, 4 ve 5). Görüldüğü gibi, devlet, devletin egemenlik erklerinden olan yargılama yetkisini kullanırken özel hukuk uyuşmazlıklarının çözümünde bireyin tercihlerine göre geriye çekilebilmektedir. ${ }^{5}$ Zaman içinde bireylerin devlet yargısına getirebileceği alternatifler çeşitlenmiş ve devlet mahkemesine alternatif olarak görülen tahkimin de ötesinde yargılamaya alternatif teşkil eden uyuşmazlık çözüm yöntemleri ortaya çıkmaya başlamıştır.

Milletlerarası ticari sözleşmelerde, hatta milletlerarası ticari uygulamada kabul görmüş tip sözleşmelerde, örneğin International Federation of Consulting Engineers ("FIDIC") tarafindan hazırlanan standart inşaat sözleşmeleri bu kapsamda zikredilebilir ${ }^{6}$, uyuşmazlığın öncelikle arabulucu, uzlaştırıcı, uyuşmazlık çözüm kurulu gibi üçüncü kişilerin dahliyle çözümlenmesi yoluna başvurulacağı, bu üçüncü kişilerin dahliyle de uyuşmazlık sulh yoluyla çözümlenemezse tahkim yoluna başvurulacağına dair uyuşmazlıkların çözümlenmesine ilişkin anlaşmalar yapilmaktadır?

Taraflar arasında bir uyuşmazlık çıkması hâlinde öncelikle arabuluculuk yoluna başvurulacağı, uyuşmazlık arabuluculuk aşamasında çözümlenemezse tahkim yoluyla çözüleceğine dair anlaşmalar İngilizce "Med-Arb" olarak ifade edilmektedir.

Türk Borçlar Kanunu, Kanun Numaras1: 6098, Kabul Tarihi: 11.01.2011, RG. 04.02.2011/27836

2 Milletlerarası Özel Hukuk ve Usul Hukuku Hakkında Kanun, Kanun Numarası: 5718, Kabul Tarihi: 27.11.2007, RG. 12.12.2007/26728)

3 Hukuk Muhakemeleri Kanunu, Kanun Numarası: 6100, Kabul Tarihi: 12.01.2011, RG. 04.02.2011/27836

4 Milletlerarası Tahkim Kanunu, Kanun Numarası: 4686, Kabul Tarihi: 21.06.2001 RG. 05.07.2001/24453

Hangi konuların bu kapsama girmediğine ilişkin örnekler için bakınız: Ali Yeşilırmak, Türkiye'de Ticari Hayatın ve Yatırım Ortamının Iyileştirilmesi İçin Uyuşmazlıkların Etkin Çözümünde Doğrudan Görüşme, Arabuluculuk, Hakem-Bilirkişilik ve Tahkim: Sorunlar ve Çözüm Önerileri (1st, On İki Levha 2011) 84, \ 148

6 http://fidic.org/bookshop (Erișim Tarihi: 05.08.2019). FIDIC tip sözleşmelerindeki çok aşamalı tahkim anlaşmaları hakkından ayrıntılı bilgi için bkz.: Nuray Ekşi, Tahkim Öncesi Uyuşmazlık Çözüm Usulleri ve Bu Usuller Tüketilmeden Tahkime Başvurulmasının Sonuçlarl ( 1st, Beta 2015) $69 \mathrm{ff}$.

Francis Russel, Russel on Arbitration (24th, Sweet \& Maxwell 2015) 2 ff; Mine Tan Dehmen, "Tahkim Öncesi Müzakere ya da Uzlaştırma Yollarının Tüketilmemiş Olmasının Tahkim Yargılamasına Etkisi” (2011) 25(1-2) MHB 451, 457.

8 Mark B. BARIL and Donald DICKEY, 'MED-ARB: The Best of Both Worlds or Just A Limited ADR Option' 1 (https:// www.semanticscholar.org/paper/MED-ARB-\%3A-The-Best of-Both-Worlds-or-Just-A-Limited-/79ffef5650e52059b27d 
Türkçe ise Arabuluculuk - Tahkim Yolu9 veya Arabuluculuk-tahkim olarak ifade edilebilir"10. "Med-Arb", tarafların uyuşmazlıklarını tarafsız bir üçüncü kişinin dahliyle sulhen çözmek, uyuşmazlık sulhen çözülemezse tahkim yoluna başvurmak konusundaki uyuşmazlık çözüm mekanizmasıdır ${ }^{11}$. Karşılaştırmalı hukukta Med-Arb ifadesi, genellikle, arabulucu ve hakemin aynı kişi olması hâlini kapsayacak şekilde dar bir anlamda kullanılmaktadır. Bu çalışmada, Arabuluculuk-Tahkim Yolu ifadesi arabulucunun aynı zamanda hakem olarak görev yapmasıyla sınırlı olmaksızın geniş anlamda kullanılmaktadır. Arabulucunun hakem olarak da görev yapması aşağıda ayrı bir başlık altında değerlendirilecektir ${ }^{12}$.

Arabuluculuk - Tahkim Yolu, tavsiyeye şayan bir uyuşmazlık çözüm yöntemi olarak görülmektedir. Zira Arabuluculuk - Tahkim Yolu, tarafları uyuşmazlıkları, kısa sürede, etkili ve daha az masrafla çözme imkânı sunar. Diğer taraftan, arabuluculuk süreci sonunda, uyuşmazlık, nihai ve bağlayıcı şekilde çözümlenemeyebilirken Arabuluculuk - Tahkim Yolunda ise arabuluculuk başarısız kaldığında uyuşmazlık hakem tarafından nihai ve bağlayıcı olacak şekilde çözülecektir. Böylece hem arabuluculuk sürecinden beklenen esneklik hem tahkimde nihai karar verilmesinin bir arada sağlanması mümkündür ${ }^{13}$.

Amerika Birleşik Devletleri’nde yapılan birkaç araştırma, tarafların tahkim aşamasında uyuşmazlık üzerindeki kontrollerini kaybedecek olmaları nedeniyle uyuşmazlığı arabuluculuk yoluyla çözmek konusunda istekli olduklarını göstermiştir ${ }^{14}$. Benzer görüşler, Hindistan için de dile getirilmiştir ${ }^{15}$.

Tahkim-Arabuluculuk Yolunun birçok Asya ülkesinde tercih edilen uyuşmazlık çözüm yolu olduğu da ifade edilmiştir. Örneğin, Çin, Hong-Kong, Japonya, Tayvan ve Singapur'da bu husus kanunlarla düzenlenmiştir ${ }^{16}$. Arabuluculuk ve tahkimin bir

320bd6b1d0081232822d, Erişim Tarihi 09/09/2019); Med-Arb’ ın değişik varyasyonları olabilir. Örneğin önce tahkime başlanması ve bir süre sonra aynı hakemin arabulucu olarak görev yapması (Arb-Med). Diğer bir ihtimal ise tahkim ve arabuluculuğun farklı hakem ve arabulucu tarafından eş zamanlı başlaması ancak arabuluculuk başarısız olursa tahkim yargılamasının devam etmesi gibi. Bkz.: Edna Sussman, 'Developing an Effective Med-Arb/Arb-Med Process' 2009 2(1) NYSBA New York Dispute Resolution Lawyer 71, 71.

9 Bu anlaşmalara yönelik “Arabuluculuk-Tahkim Yolu” nitelendirmesi için bkz: Gülgün Ildır, Alternatif Uyuşmazlık Çözümü (1st, Seçkin 2003) 100; Mustafa Serdar Özbek, ‘Arabuluculuk ile Tahkim Yöntemlerinin Kesișme Bölgesi: ArabuluculukTahkim’ 2017 43(1) Yargitay Dergisi 15, 106.

10 Güven Yarar, Milletlerarası Özel Hukukta Arabuluculuk (1st, On İki Levha 2019) 31.

11 Ildır 100; İhsan Berkhan, Tahkim ve Arabuluculukta Tarafsızlık Illkesi, (1st, Aristo 2019) 24; Martin C. Weisman, 'Med -Arb: The Best of Both Worlds' 2013 19(40) Dispute Resolution Magazine 40, 41; A. Pappas Brian, 'Med-Arb and the Legalisation of Alternative Dispute Resolution' 2015 20(157) Harv. Negot. L. Rev. 157, 159; M. Elizabeth Telford, Med-arb: a viable dispute resolution alternative (1st IRC 2000), i; Deekshita Srikant and Saha Arka, 'Amalgamating The Conciliatory And The Adjudicative: Hybrid Processes And Asian Arbitral Institutions' 2014 III(1) Indian Journal of Arbitration Law 76, 77; Richard Fullerton, 'The Ethics of Mediation - Arbitration' 2009 38(5) The Colorado Lawyer 31, 31.

12 Bkz. yuk. V.A.

13 Ayrıntılı bilgi için bkz.: Telford 2 ff.; Brian 159; Baril, Dickey, 4; Berkhan 24.

14 Weisman 40; Telford 3; Arabuluculuk - Tahkim Yolunun sağladığı avantajlar hakkında bkz. Brian 157-203, 167-168; Yarar 32.

15 Srikant and Arka 78.

16 Ibid 82. Yarar 31. 
arada yer almasının faydası ve bu yöntemin tavsiye edilmesinin nedeni, arabuluculukta nihai bir karar verilmiyor olmasına ilişkin eksikliğin arabuluculuğu takip eden tahkim sayesinde giderilebilmesidir ${ }^{17}$.

15 Kasım 2019 tarihinde, İstanbul Tahkim Merkezi, dünyada ilk defa ArabuluculukTahkim Kuralları yayınlamıştır ve Kurallar yürürlüğe girmiştir ${ }^{18}$. ISTAC, Kurallar’da “Arabuluculuk-Tahkim" (Mediation-Arbitration) ifadesini kullanmıştır. ISTAC, Arabuluculuk-Tahkimi, birbirinden farklı uyuşmazlık çözüm mekanizması olan arabuluculuk ve tahkimin aynı uyuşmazlık çözümü sürecinde iki aşamalı olarak birlikte kullanılmasını sağlayacak bir uyuşmazlık çözüm yöntemi olarak ifade etmiştir ${ }^{19}$.

Bu çalışmada, arabuluculuk yönteminin öncelikle denenmesi ancak arabuluculuk yöntemiyle uyuşmazlığın çözümlenememesi hâlinde uyuşmazlığın tahkim yoluyla çözümlenmesini öngören anlaşmaların sonuçlarına değinilmektedir.

\section{Tahkim ve Arabuluculuk Arasındaki Temel Farklar}

Arabuluculuk ve tahkime bir arada yer veren uyuşmazlık çözümü anlaşmaların1 ${ }^{20}$, daha iyi değerlendirebilmek için tahkim ve arabuluculuk arasındaki temel farklara değinmek gerekir ${ }^{21}$.

Tahkim, çekişmeli bir yargılamadır. Hakemler, uyuşmazlık üzerinde yargılama yetkisine sahiptir. Hakem, vakıaların nasıl gerçekleştiği hakkında vicdani bir kanaate varır ve hukuk kurallarını uygulayarak hangi tarafın haklı olduğu konusunda tarafları bağlayııı ve nihai bir karar verir ${ }^{22}$. Karar, yasal şartlar gerçekleşince, şekli ve maddi anlamda kesin hüküm teşkil eder. Hakem kararları da mahkeme kararları gibi ilamlı icra yoluyla icra edilir. İspat yükü, ispat ölçüsü, iddiaları somutlaştırma yükü, delil ikame yükü devlet yargısında olduğu gibi tahkim yargılamasında da uygulama alanı bulur. Hakem, tıpkı hâkim gibi, tarafların iddia ve savunmalarını dinler, delillerini inceler ve tarafların sundukları beyanları ve delilleri çerçevesinde vicdani kanaatini

\footnotetext{
7 Brian 167; ayrica bkz.: Ildır 89.

18 https://istac.org.tr/wp-content/uploads/2019/11/ISTAC-Arabuluculuk-Tahkim-Kuralları-Med-Arb.pdf (Erişim Tarihi 24.11.2019).

19 https://istac.org.tr/istac-med-arb-kurallarini-ilan-etti/ (Erişim Tarihi 24.11.2019).

20 Uygulamada yazılı sözleșmelerde "uyușmazlıkların çözümü" kenar başlığını tașıyan bir sözleșme hükmüyle karşılaşılmaktadır. Uyuşmazlıkların çözümüne ilişkin bu hükümde, taraflar söz konusu sözleşmeden doğan uyuşmazlıkların nasıl çözümleneceğine ilişkin anlaşmalarına yer vermektedir. Uyuşmazlıkların çözümüne ilişkin bu hükümde, taraflar uyuşmazlığın devlet yargısınca çözümlenecekse yetkili mahkemeyi seçebilirler. Taraflar, tahkim anlaşması yapabilir. Alternatif çözüm yöntemlerine yer verebilir. Böylece, uyuşmazlıkların çözümüne ilişkin bu anlaşmalarda, arabuluculuk anlaşması, tahkim anlaşması, uyuşmazlığın esasına uygulanacak hukuk konularındaki anlaşmaları yer alır. Bilindiği üzere, hukuk seçimi, yetkili mahkemelerin belirlenmesi ve tahkim anlaşmaları asıl sözleșmeden bağımsız diğer bir ifadeyle geçerlilikleri asıl sözleşmenin geçerliliğine bağlı olmayan anlaşmalardır. Bu çalışmada, arabuluculuk ve tahkim anlașmalarının bir arada yer alması ihtimali incelenmektedir. Bu nedenle, arabuluculuk ve tahkim anlaşmasının bir arada olduğu anlaşmalar için tahkim anlaşması ifadesini kullanmak isabetli değildir. Zira tahkim anlaşması arabuluculuğa ilişkin anlaşmayı da kapsamayacaktır. Biz çalışmamızda uyuşmazlık çözümü anlaşması ifadesini kullanmayı uygun bulduk.

21 Bu konuda daha ayrıntılı bilgi için bkz.: Baril, Dickey 2-3; Yarar 26-27.

22 MTK.m12 uyarınca "Hakem veya hakem kurulu, ancak tarafların açıkça yetkili kılmış olmaları şartıyla hakkaniyet ve nasafet kurallarına göre veya dostane aracı olarak karar verebilir.”Dostane aracı olarak hareket eden hakemler, hukuk kurallarına göre karar vermezler.
} 
tesis edip hüküm verir. İspatlanamayan konularda ise ispat yükünü taşıyan taraf, iddiasının dayanağı olan vakıaların ispat edilememesinin sonuçlarına katlanır.

Arabuluculuk ise yargılama dışı bir uyuşmazlık çözüm faaliyetidir. ${ }^{23}$ Arabulucu, sistematik teknikler uygulayarak, görüşmek ve müzakerelerde bulunmak amaciyla tarafları bir araya getirir. Tarafların birbirlerini anlamalarını ve bu suretle çözümlerini kendilerinin üretmesini sağlamak için ${ }^{24}$ aralarında iletişim sürecinin kurulmasını sağlar. ${ }^{25}$ Tarafların çözüm üretemediklerinin ortaya çıkması hâlinde arabulucu uyuşmazlığın çözülmesi için kendi önerisini getirebilir. ${ }^{26} \mathrm{~K}$ ssaca, arabulucu esasında tarafları bir araya getirmekte ve onların çözümlerini bulmalarını sağlamakta ve uyuşmazlık sulh ile çözülmektedir. ${ }^{27}$

Türk Hukukunda, Hukuk Uyuşmazlıklarında Arabuluculuk Kanunu ("HUAK") 28, arabuluculuk faaliyetini tahkim yargılamasından ayıran bu temel hususları açıkça ortaya koymaktadır. Bu çerçevede, taraflar çözüm üretemezse arabulucu bir çözüm önerebilir ancak önermek zorunda değildir (HUAK.m15(7)). Arabulucu, arabuluculuk için daha fazla çaba sarf edilmesinin gereksiz olduğunu tespit ederse taraflara danıştıktan sonra arabuluculuk faaliyetini sona erdirebilir (HUAK.m17(1)(b)). Dolayısıyla, arabulucu, taraflar kendi çözümlerini üretemediklerinde uyuşmazlığ sona erdirmek için bir çözüm üretmek ve uyuşmazlığı sona erdirmek zorunda değildir. Üstelik arabulucu bir çözüm üretse de bu tavsiye niteliğinde olacaktır ve bağlayıcı değildir. Zira arabuluculuk bir yargılama ve karar mekanizması değildir. ${ }^{29}$ Arabulucu, tarafların menfaatlerine ilişkin uyuşmazlıkların ortadan kaldırılması amaciyla taraflara yardım eder. ${ }^{30}$

Tahkim yargılamasına son verilebilecek haller ise MTK'nın 11 ve 13 maddelerinde sayılmaktadır. Tahkimi sona erdiren sebepler arasında tarafların kendi uyuşmazlıklarını çözmek için bir çözüm üretememeleri veya hakemlerin, davacı davasını takip etmekten vazgeçmedikçe, uyuşmazlığın çözüme kavuşabilmesi için yargılamaya devam edilmesini faydasız bulmaları gibi haller sayılmaz.

Arabuluculuk faaliyeti sirasinda, taraflardan bir tanesi arabuluculuk faaliyetinden çekildiğini bildirebilir (HUAK.m17(1)(c)). Tahkimde ise davacının davasından feragat etmesi veya davacının davalının muvafakatiyle davasını geri alması dışında

23 Ildır 23; Yeşilırmak 18.

24 Ibid 24-25; Elif Kısmet Kekeç, Arabuluculuk Yoluyla Uyuşmazlık Çözümünde Temel Aşamalar ve Taktikler (1st Adalet 2011) 27.

25 Kekeç 23.

26 Krş.: Gizem Ersen Perçin, 'Alternatif Uyuşmazlık Çözüm Yöntemlerinden Arabuluculuğun Hukuksal Düzenlemelerdeki Yeri’ 2011 31(2) Public and Private International Law Bulletin 177, $177 \mathrm{ff}$.

27 Kekeç 24.

28 Hukuk Uyuşmazlıklarında Arabuluculuk Kanunu, Kanun Numarası: 6325, Kabul Tarihi: 07.06.2012, RG. 22.06.2012/28331

29 Ziya Akıncı, Milletlerarası Tahkim (4th Vedat 2016) 10.

30 Kekeç Birinci Bölüm § 4.C. 
taraflardan bir tanesinin tahkimden çekildiğini bildirmesi yargılamayı sona erdirmez (HMK.m435, MTK.m13(b)). Davalının davaya iştirak etmemesi hâlinde ise yarg1lamaya devam edilir (HMK.m430(1)(b, c), MTK.m11(c)(3,4)).

Tüm bunlara ek olarak, tahkime başvurulması zamanaşımını keser. Arabuluculuğa başlanması ise zamanaşımını ve hak düşürücü sürelerin işlemesini durdurur ama kesmez (HUAK.m16(2)).

Sonuç olarak, arabuluculuk ve tahkim birbirlerinden son derece farklıdır. Tahkim, bir uyuşmazlığın yargılama faaliyeti sonucunda ilamlı icra yoluyla icra edilebilir bir hakem kararı verilmesi suretiyle nihai olarak çözüme bağlanmasını hedefler. Arabuluculuk ise genellikle henüz bir uyuşmazlık nedeniyle tahkim veya devlet mahkemeleri huzurunda dava açmadan tarafların bir araya gelerek uyuşmazlığı sulhen çözmelerine hizmet eder. Bu itibarla, arabuluculuk, tahkim yoluna başvurmadan önce denenecek bir uyuşmazlık çözüm faaliyeti olarak bir ön basamak teşkil edebilir. Diğer bir ifadeyle, tahkim ve arabuluculuk arasındaki ilişki, arabuluculuk ile mahkemeler arasındaki ilişki gibidir. Arabuluculuk, mahkemeler huzurundaki yargılamaya alternatif olduğu ölçüde tahkime de alternatiftir. ${ }^{31}$

\section{Hukuk Uyuşmazlıklarında Arabuluculuk Kanunu'nun Tahkime İlişkin Yasal Düzenlemelerle İlişkisi}

Hukukumuzda milli ve milletlerarası tahkim farklı kanunlara tabidir. Milletlerarası tahkim 4686 sayılı MTK'ya tabidir. Kanunun birinci maddesi uyarınca, yabancılık unsuru taşıyan uyuşmazlıklar milletlerarası niteliktedir ve MTK'ya tabidir. HMK ise MTK kapsamında yabancılık unsuru taşımayan ve tahkim yerinin Türkiye olduğu tahkimleri milli tahkim olarak nitelemekte ve milli tahkimi düzenlemektedir (HMK.m407).

Hukuk Uyuşmazlıklarında Arabuluculuk Kanunu'nun birinci maddesinin ikinci fikrası uyarınca ${ }^{32}$, Kanun, yabancılık unsuru taşıyanlar da dâhil olmak üzere, ancak tarafların üzerinde serbestçe tasarruf edebilecekleri iş veya işlemlerden doğan özel hukuk uyuşmazlıklarının çözümlenmesinde uygulanır ${ }^{33}$.

Uyuşmazlık çözüm anlaşmasında arabuluculuk ve tahkim bir arada yer alıyorsa, uyuşmazlık yabancılık unsuru içerse de içermese de arabuluculuk faaliyetine Hukuk Uyuşmazlıklarında Arabuluculuk Kanunu uygulanacaktır. Tahkim yargılamasına başvurulan hallerde ise uyuşmazlığın yabancı unsurlu olup olmamasına göre MTK veya HMK uygulanacaktır.

31 Karş.: Özbek 20.

32 Bununla birlikte HUAK.m18/A/18 uyarınca "özel kanunlarda tahkim veya başka bir alternatif uyuşmazlık çözüm yoluna başvurma zorunluluğunun olduğu veya tahkim sözleşmesinin bulunduğu hâllerde, dava şartı olarak arabuluculuğa ilişkin hükümler uygulanmaz.

33 Millî ve Milletlerarası Arabuluculuk tanımları için bkz.: Necla Öztürk, ‘Arabuluculuğun Milletlerarası Özel Hukuk Boyutu: Genel Bakış’ 2015 31(2) Batıder 203-256, 210-214. 


\section{Arabuluculuk - Tahkim Anlaşmaları}

\section{A. Arabuluculuk - Tahkim Anlaşmalarının Geçerliliği}

Taraflar, uyuşmazlık çözümü anlaşmasında, uyuşmazlığın öncelikle arabuluculuk faaliyetiyle çözülmeye çalışılacağını, arabuluculuk faaliyetinden sonuç alınamaması hâlinde tahkime başvurulacağını kararlaştırabilir. Zira yukarıda ifade ettiğimiz gibi arabuluculuk faaliyetine rağmenuyuşmazlıknihaiolarakçözümekavuşturulamayabilir ve tarafların arasında uyuşmazlığın yargılama yapılması suretiyle sona erdirilmesi gerekebilir. Bu şekildeki, -basamaklı ya da çok aşamalı olarak ifade edilentahkim anlaşmaları geçerlidir. Zira uyuşmazlığın arabuluculuk faaliyeti sonucunda çözümlenememesi hâlinde uyuşmazlığın tahkim yoluyla çözümleneceğine dair taraf iradeleri tereddüde yer vermeyecek kadar açıktır ${ }^{34}$.

Bununla birlikte, arabuluculuğa ve tahkime bir arada yer veren bir tahkim anlaşması, son derece dikkatli kaleme alınmalıdır. Zira Yargıtay'ın müstakar kararlarına göre, geçerli bir tahkim anlaşmasından söz edebilmek için tarafların uyuşmazlığın tahkim yoluyla çözülmesine ilişkin taraf iradelerinin herhangi bir tereddüde yer vermeyecek şekilde açıkça anlaşılabiliyor olması gerekir. Aksi halde, tahkim anlaşması geçersiz kabul edilmektedir. Bu kapsamda Yargıtay, özellikle, uyuşmazlığın ilk önce taraflarca atanacak hakemler tarafindan çözümleneceğine ve hakemler tarafından çözümlenemezse mahkemelerde dava açılacağına dair uyuşmazlık çözümü anlaşmalarını geçerli bir tahkim anlaşması saymamışıır ${ }^{35}$.

Lindsay v. Lewandowski $i^{36}$ kararı çok aşamalı tahkim anlaşmalarının geçerliliğine ilişkin bir ABD mahkeme kararıdır. Karara konu olan olayda, taraflar, arabuluculuk aşamasının başarısız olması hâlinde arabulucunun "bağlayıcı arabuluculuğa" devam edecekleri konusunda anlaşma yapmışlardır. ABD mahkemesi "bağlayıcı arabuluculuk" gibi bir usulün var olmadığ 1 ve böyle bir usule arabuluculuk ya da tahkim kurallarından hangisinin uygulanması gerektiğinin bilinmemesi karşısında uyuşmazlık çözüm yolu anlaşmasını geçersiz saymıştır. Kararda, tarafların arabulucunun hakem olarak görev yapmasına ilişkin ifadelerinin herhangi bir şüpheye yer vermeyecek şekilde açık olması hâlinde arabulucunun hakem olarak karar verebileceği belirtilmiştir ${ }^{37}$.

\footnotetext{
34 Yargıtay 15. Hukuk Dairesi 1987 ve 1995 yıllarında verdiği iki kararında FIDIC tarafından hazırlanan standart inşaat sözleşmenin 1987 tarihli versiyonun 67. maddesinde yer alan tahkim anlaşmasının geçerliliğini tartıșmıștır. 15. Hukuk Dairesi, 67. maddede yer alan taraflar arasındaki uyuşmazlığın öncelikle Mühendis tarafından karara bağlanacağına ve taraflardan birisinin Mühendis'in kararına itiraz etmesi ve diğer tarafa tahkime başvurma iradesini bildirmesi hâlinde tahkime başvurabileceğine ilişkin düzenlemenin geçerli bir tahkim anlaşması olduğuna karar vermiştir. Bu konuda bkz.: Ekşi 47-49; Tan Dehmen 460.

35 Örneğin: Y. 15. HD., 13.11.2017 t. 5313/3922; Y. 15. HD., 13.11.2017 t. 10552/256; Y. 23. HD. 26.05 .2014 t., 887/4043; Y. 15. HD., 09.02.2017 t., 5600/512 (Kararlar için bkz.: Lexpera Hukuk Otomasyonu).

36 Lindsay v. Lewandowski (2006) 43 Cal. Rptr. 3d 846, 853

37 Sussman 73.
} 
Uluslararası Barolar Birliği'nin Milletlerarası Tahkim Anlaşmalarının Kaleme Alınmasına İlişkin Kılavuzunda ${ }^{38}$, çok aşamalı tahkim anlaşmaları hazırlanırken dikkat edilmesi gereken üç husus ifade edilmiştir. Bunlardan ilki uyarınca, çok aşamalı tahkim anlaşması, tahkim öncesi aşamada başvurulacak müzakerelerin veya arabuluculuğun ne kadar süreceğine ve tahkimin hangi vakıanın gerçekleşmesi üzerine başlatılacağına ilişkin (örneğin yazılı bir talep) açık bir düzenleme içermelidir. İkinci olarak, tahkim öncesi uyuşmazlık çözümü aşamasının başarısız olması hâlinde uyuşmazlığın tahkim yoluyla çözülmesi, ihtiyari değil bağlayıcı olarak anlaşılacak şekilde kaleme alınmalıdır. Son olarak, hakkında tahkim öncesi çözüm yöntemlerine ve akabinde tahkime başvurulacak uyuşmazlık konularının aynı olmasına dikkat edilmelidir ${ }^{39}$.

Öncelikle arabuluculuk faaliyetine başvurma, eğer uyuşmazlık arabuluculuk ile çözümlenemezse bu defa nihai ve bağlayıcı olarak uyuşmazlığı çözüme kavuşturmak için tahkime başvurma yönündeki taraf iradelerinin, tereddüde yer vermeyecek derecede açık olarak ifade edilmemesi hâlinde tahkim anlaşmasının geçerliliğini tehlikeye atacağını söyleyebiliriz. Örneğin, uyuşmazlıkların arabuluculuk aşamasında çözümlenememesi hâlinde tahkim yoluna "başvurulabileceği" şeklindeki bir düzenleme tahkime başvurmanın tarafların seçimine bırakılması şeklinde yorumlanabilir ${ }^{40} \mathrm{ki}$ bu durumda uyuşmazlığın tarafların tercihine göre çözümlenmesi söz konusu olacaktır. Tahkim anlaşmasının geçersiz sayılması hâlindeyse arabuluculuk faaliyeti sonucunda çözümlenemeyen uyuşmazlık nihai olarak devlet mahkemeleri huzurunda çözümlenecektir.

\section{B. Arabuluculuk Yoluna Başvurulmadan Tahkime Başvurulmasının Sonuçları}

Davac1, arabuluculuk faaliyeti sonucunda uyuşmazlığın çözülebileceğine inanmıyorsa, örneğin davalı, davacının samimi sulh girişimlerini sonuçsuz bırakmışsa, artık, arabuluculuk faaliyetine başvurmak suretiyle daha fazla zaman kaybetmek ve masrafa katlanmak yerine tahkime başlamak isteyebilir. Tahkim davasının başlaması üzerine, davalı, arabuluculuk faaliyetine başvurulmamasının tahkimin başlamasını engelleyen bir ön şart olduğu iddiasıyla hakemlerin henüz uyuşmazlık hakkında karar veremeyeceğini iddia edebilir. Davalının itirazı, davacının davasının tahkim yargılamasına henüz konu olamayacağına ilişkindir. Davalı tahkime başvurunun ön şartının arabuluculuğun başarısızlıkla sonuçlanması olduğunu ve bu şart gerçekleşmeden tahkim yargılamasının başlayamayacağını iddia etmektedir. Diğer bir ifadeyle burada şarta bağlı bir tahkim anlaşması vardır ve şart henüz gerçekleşmediği

\footnotetext{
Uluslararası Barolar Birliği'nin Milletlerarası Tahkim Anlaşmalarının Kaleme Alınmasına İlişkin Kılavuz, Uluslararası Barolar Birliği, 07.10.2010. https://www.ibanet.org/Publications/publications_IBA_guides_and_free_materials.aspx (Erişim Tarihi 28.09.2019).

39 https://www.ibanet.org/ENews_Archive/IBA_27October_2010_Arbitration_Clauses_Güçuidelines.aspx (Erişim Tarihi 28.09.2019). Bkz.: EKŞí, s. 25.

40 Uluslararası Barolar Birliği Milletlerarası Tahkim Anlaşmalarının Kaleme Alınmasına İlişkin Kılavuz s. 90. Bkz.:https:// www.ibanet.org/ENews_Archive/IBA_27October_2010_Arbitration_Clauses_Guidelines.aspx (Erişim Tarihi 28.09.2019)
} 
için tahkime taraf olma yükümlülüğü davalı için henüz doğmamıştır. Bu aşamada tahkim yargılamasının başlatılması, "premature" olarak ifade edilmektedir. ${ }^{41}$

Tarafların uyuşmazlığın arabuluculuk yoluyla çözülmesine yatkın olmadığı hâllerde, tahkim davası başlatılmadan önce arabuluculuk yolunun tüketilmesinin bir ön şart olarak kararlaştırılması, tahkimin başlamasını geciktirmek isteyen taraf için adeta bir firsata dönüşebilir. ${ }^{42}$ Dolayısıyla, arabuluculuk yolu tüketilmeden tahkime başlanmasının mümkün olmadığına ilişkin davalı itirazı, hakemler tarafından karara bağlanırken bu hususun da göz önünde bulundurulması gerekir.

Hakemler, taraflar arasında uyuşmazlık çözüm anlaşması uyarınca arabuluculuk faaliyetinin başarısızlıkla sonuçlanmasının tahkim anlaşmasının hüküm ve sonuç doğurmasının şartı olup olmadığı hakkında karar vermelidir. Kararlarını verirken hakemler, uyuşmazlık çözümü anlaşmasının ifade tarzını ve tarafların uyuşmazlık çözüm anlaşması müzakereleri sırasındaki davranışlarını inceleyerek uyuşmazlık çözüm anlaşmasını yorumlamalıdır. Tahkimde davanın başlatılabilmesi için arabuluculuk yoluna başvurulması zorunlu ya da ihtiyari olabilir ${ }^{43}$. Hakemler, arabuluculuğun tüketilmesinin tahkim anlaşmasının hüküm ve sonuç doğurmasının zorunlu bir önşartı olduğuna karar verirlerse tarafların tahkim yoluna başvurmadan önce arabulucuya başvurmaları gerekir ${ }^{44}$. Milletlerarası tahkim uygulamasında, arabuluculuğa başvurmadan tahkim yargılamasının başlatıldığı hallerde, davalının itiraz etmesi üzerine, hakemler, davayı reddetmek yerine yargılamayı durdurup, tarafların uyuşmazlıklarını arabuluculuk faaliyetiyle çözmeye çalışmalarını tercih etmektedirler. $\mathrm{Bu}$ hâlde taraflar, arabuluculuk faaliyetinden bir sonuç alamaz ve uyuşmazlıklarını çözemezlerse yargılamaya kaldığı yerden devam edilebilecektir. ${ }^{45}$

41 Sanl 1 450; Tan Dehmen 463 ff; krş.: Ersen Perçin 187.

42 Uluslararası Barolar Birliğinin Tahkim Anlaşmasının Kaleme Alınmasına ilişkin kılavuzunda, tarafların bu süreci tahkimi geciktirmek için kötüye kullanılmasını engelleyici bir tedbir olarak tahkim öncesi uyuşmazlık çözüm aşamasının ne kadar süreceğine ilişkin sınırlama getirilmesi ve bu sürecin ne şekilde başlatılmasının gerektiğine ilişkin açık bir hükme yer verilmesi önerilmiştir. Bkz. Kılavuz s. 87 Bkz.: https://www.ibanet.org/ENews_Archive/IBA_ 27October_2010_ Arbitration_Clauses_Guidelines.aspx (Erişim Tarihi 28.09.2019)

43 Russel 2 ff; Ekşi 27 ff; Tan Dehmen 459.

Hakem heyeti davalı devletin tahkim öncesi dostane sulh görüşmelerini yerine getirmemiş olmasının tahkime başlamayı engellemeyeceğini zira somut olayın özellikleri dikkate alındığında dostane müzakerelerinin olası bir sulhu sağlamakta faydasız olacağının anlaşıldığına ve tahkim yargılamasının devam etmesine karar vermiștir. (Bkz.: Ethyl Corp v. The Government of Canada, UNCITRAL, Award on Jurisdiction, If 75 (https://www.italaw.com/sites/default/files/casedocuments/ita0300_0.pdf (Erișim Tarihi 05.08.2019).

Başka bir kararda da dostane görüşmelerin faydasız kalacağı anlaşılabiliyorsa tarafların dostane görüşmelere başlamadan tahkim yoluna bașvurabileceklerine karar verilmiștir (Abaclat and Others v. Argentine Republic, ICSID Case No. ARB/07/5, Decision on Jurisdiction and Admissibility, $564 \mathrm{https} / /$ www.italaw.com/cases/35 (Erişim Tarihi 05.08.2019)

Başka bir hakem kararında hakemler, tahkim öncesi uyuşmazlık çözümü sürecinin her iki tarafın da iyiniyetli ve samimi çabalarını gerektirdiğini, diğer bir ifadeyle, tahkim öncesi uyuşmazlık çözüm sürecinin davacının daha fazla yargılama masrafına katlanmasına ve zaman kaybetmesine neden olmaması gerektiğini ifade etmiștir. Bkz.: ICC Case No. 14079 (ICC Bulletin, 2014, Vol 25 - Supplement, Procedural Decisions in ICC Arbitration)

44 Krş.: Akıncı 11; Ekşi 55.

45 Russel 2 ff; Gary Born, International Commercial Arbitration "Formation, Validity and Legality of International Arbitration Agreements" (2nd, Wolters Kluwer Law \& Business 2014) 932; Christopher Boog, "How to Deal with Multitiered Dispute Resolution Clauses - Note - 6 June 2007 - Swiss Federal Supreme Court' 26(1) 2008 ASA Bulletin 111, 112; Ekşi 40-43 arasında önceki aşamanın tüketilmemesinin tahkimde itiraz konusu olması hâlinde hakemlerin bekletici mesele yapabileceğine ilişkin görüşlere ve hakem kararlarına işaret edilmiştir. Ancak Yazar, kendi görüşünü açıladığı ve 46. ve 55. sayfalarda önceki aşamaya başvurulmadan tahkime başvurulmasının sözleşmenin ihlali olduğunu ve tarafların önceki 
Milletlerarası tahkim uygulamasında genel kabul gören bu yaklaşım İstanbul Tahkim Merkezi Arabuluculuk-Tahkim Kuralları'nın 4üncü maddesinin 5inci fikrasında açıkça ifade edilmiştir. Buna göre "taraflardan biri arabuluculuk süreci başlamadan, arabuluculuk süreci sona ermeden ve her halükarda arabuluculuk süreci başladıktan sonra sekiz hafta geçmeden önce tahkim davası açarsa, karşı taraf en geç cevap dilekçesinde tahkim yargılamasının durdurulmasını ve arabuluculuk sürecinin başlatılmasını veya kaldığ yerden devam etmesini talep edebilir. Hakem kurulunun tahkim yargılamasını durdurmaya karar vermesi üzerine arabuluculuk süreci başlar. Arabuluculuk süreci tarafların anlaşamaması nedeniyle sona ererse taraflardan birinin talebi üzerine tahkim yargılaması kaldı̆̆ yerden devam eder. Hakem kurulu, karşı tarafin talebi üzerine arabuluculuk-tahkim sözleşmesinin ihlalinden doğan zararın karşılanması için için uygun bir tazminata hükmedebilir." $\mathrm{Bu}$ madde uyarınca, hakemler, arabuluculuğun tahkime başvuru hakkının bir önkoşulu olduğunu kabul etmeleri hâlinde tahkim yargılamasına bu gerekçeyle son veremezler. Böylece uygulamada doğabilecek tereddütlerin önüne geçilmiş olması bakımından takdir edilmesi gereken bir düzenleme yapılmıştır.

Hakemler, arabuluculuğun bir ön şart olmadığına karar verirlerse davalının itirazlarını reddederler ve uyuşmazlığ 1 esastan incelemeye başlayabilirler.

\section{Arabuluculuk Tahkim Yolunun Bir Uyuşmazlık Çözüm Yöntemi Olarak Değerlendirilmesi}

Arabuluculuk-Tahkim Yolunda, tarafların uyuşmazlıklarını yargılama yerine üçüncü kişilerin yardımıyla sulh yoluyla çözmeye çalışmaları teşvik edilmekte, uyuşmazlık sulh yoluyla çözülemezse tahkim edilmektedir.

Hukuki bir uyuşmazlığın ortaya çıkması hâlinde taraflar arasında psikolojik bir gerginlik ortaya çıkabilir ve taraflar uyuşmazlığın çözülmesi için bir araya gelip sorunu müzakere edemez hâle gelebilirler. Bu durumda ancak tarafsız üçüncü bir kişinin dahliyle taraflar uyuşmazlıklarını müzakere etmeye başlayabilir. Müzakereler sonucunda uyuşmazlığın çözülmesi mümkün olabildiği için, arabuluculuğun tahkimin bir alternatifi olabileceği iddia edilmektedir. Bu beklentiye göre, taraflar zaman içinde tahkim yerine arabulucuya başvurmak suretiyle uyuşmazlıklarını çözeceklerdir ve tahkimin uygulama alanı daralacaktır. Örneğin, ABD'de ticari uyuşmazlıklarda arabuluculuk yöntemi yaygın olarak kullanılmaktadır ${ }^{46}$ ve yazarlar,

usulleri tüketmeden tahkime başvuramayacağını ifade etmiş ancak yine de tahkime başvurulması hâlinde hakemlerin bekletici mesele yapma kararı veremeyeceğini açıkça belirtmemiştir. Buradan hareketle Sayın Prof. Dr. Ekşi'nin hakemlerin yargılamayı durdurup tarafların öncelikle arabuluculuk yoluna tüketmelerine karar veremeyeceği kanaatinde olduğu sonucuna variyoruz.

ICC Case No. 14431 tahkim yargılamasında, hakemler yargılama yetkileri olmadığı gerekçesiyle davayı reddetmek yerine tarafların uyuşmazlık çözüm kuruluna başvurmaları için yargılamanın durmasına ve bu şekilde taraflar uzlaşamazsa yargılamanın devam etmesine karar vermişlerdir ('Dispute Adjudication Boards Under FIDIC Contracts' 2015131.

46 ABD'de Arabuluculuk-Tahkim Yolunun bir uyuşmazlık çözüm yöntemi olarak değerlendirilmeye başlanması 1940'lara tarihlenmektedir. Telford 1; Thomas J. Stipanowich, Jung Yang, Jay Welsh, Chen Qiming, Peter Robinson, Tan Jinghui, Chen 
arabuluculuğun gittikçe tahkime yaklaştığını ve onun yerini almaya başladığını ifade etmişlerdir ${ }^{47}$.

Şüphesiz, uyuşmazlıkların yargılama yerine barışçıl girişimlerle sulh yoluyla çözülmesi, en azından toplumsal hoşgörü ve barış için, tercihe şayandır. Dikkatimizi çeken vakıa şudur ki, arabuluculuk ya da diğer üçüncü kişilerin müdahalesiyle uyuşmazlıkların çözülmesi 20. yüzyılın ikinci yarısında bugünkü önemine ulaşmaya başlamakla beraber ${ }^{48}$ çok eskiden beri bilinmektedir. Roma Hukuku'nda, tahkim devlet yargısının bir alternatifi olarak mevcuttu. Tıpkı günümüzde olduğu gibi hakemler yetkilerini taraflar arasındaki anlaşmadan almaktaydı ancak hakem kararları bağlayıcı değildi. Mecelle'de de tahkim bir yargılama yöntemi olarak mevcuttu ${ }^{49}$. Türkiye'de bu yöndeki tartışmalar ve yasama faaliyetleri görece yenidir ancak bireylerin uyuşmazlıklarını çözmek için üçüncü bir kişiye başvurmaları yeni değildir. $\mathrm{Bu}$ açıdan bakıldığında arabuluculuk geçilen yüz yılların sonunda tahkimin yerini alamamıştır ve geçmişten hareketle bir perspektif yapılacak olursa arabuluculuğun tahkimin yerini alamayacağını söyleyebiliriz.

Bugün geldiğimiz noktada, özellikle milletlerarası ticaretin aktörleri -tacirler, milletlerarası ticaret odaları, milletlerarası meslek örgütleri- uyuşmazlıkların yargılamaya başvurulmadan önce üçüncü kişilerin müdahalesi -arabuluculuk, uzlaştırıcı, uyuşmazlık çözüm kurulu- ile çözümlenmesini düzenleyen tip sözleşme ve kurallara yer vermektedir. Hazırlanan(tip) sözleşmelerde tahkime başvurmadan önce üçüncü bir kişinin dahlini içeren alternatif uyuşmazlık çözüm yöntemlerinden birisine başvurulmasına yer verilmektedir. Örneğin, inşaat sektöründe yaygın olarak kullanılan 2017 FIDIC Tip Sözleşmelerinin 20. maddesinde tahkimden önce uyuşmazlık çözüm kuruluna başvurulması, uyuşmazlık çözüm kurulunun faaliyetleri sonucu uyuşmazlık çözümlenemezse tarafların 56 gün boyunca uyuşmazlığı müzakerelerle çözmeye çalışmaları bu şekilde uyuşmazlık çözümlenemezse tahkime başvurulması düzenlenmektedir.

Taraflar arasında bir uyuşmazlık çıkması hâlinde öncelikle arabuluculuk faaliyetine başvuracaklarını ve arabuluculuk faaliyetinin sonuçsuz kalması hâlinde tahkime başvurabileceklerini düzenleyen bir uyuşmazlık çözümü anlaşması tarafların tahkime başvurmak yerine arabuluculuk yoluyla uyuşmazlığı sona erdirmelerini sağlamakta beklendiği kadar etkili midir sorusunun sorulması gerektiği kanaatindeyiz.

Öncelikle soruya verilecek yanıt, somut uyuşmazlığın taraflarının özelliklerine göre değişir.

Guang, Jeff Kichaven, Denise Madigan, Wang Hongsong, Zhang Jianhua, 'East Meets West: An International Dialogue on Mediation and Med-Arb in the United States and China' 2009 2(9) Pepp. Disp.Resol. L.J. 384 (https://digitalcommons. pepperdine.edu/drlj/vol9/iss2/5 Erişimi Tarihi 3/09/2019)

47 Brian 164; Stipanowich, Yang, Welsh, Qiming, Robinson, Jinghui, Guang, Kichaven, Madigan, Hongsong, Jianhua 380.

48 Ayrıntılı bilgi için bkz.: Ildır 31 ff; Öztürk 205.

49 Kekeç 30 ff; Ildır 31 ff; Örneğin Çin'de arabuluculuğun binlerce yıl eskiden beri var olduğu ifade edilmiştir. Stipanowıch, Yang, Welsh, Qiming, Robinson, Jinghui, Guang, Kichaven, Madigan, Hongsong, Jianhua 380. 
Milletlerarası ticaretin aktörlerinin dikkate değer bir bölümü, uzun ve kısa vadeli ticari menfaatlerini ön planda tutarak bir uyuşmazlığın yargıya taşınmasına ya da taşınmamasına karar verir. Arabulucunun görevi, tarafları sözleşme veya hukuk kuralları uyarınca sahip oldukları haklardan ziyade, gerçek menfaatlerinin ne olduğunu değerlendirmeye teşvik etmektir ${ }^{50}$. Uygulamada, taraflar, uğranılan zararın giderilmesinden ziyade başkaca ticari menfaatlere sahiplerse uyuşmazlık çıkarmaktan son ana kadar kaçınır. Örneğin, milletlerarası inşaat sözleşmelerinde müteahhidin karşısındaki işsahibi genellikle bir kamu kurumu veya güçlü bir gayrimenkul geliştirme şirketidir. Müteahhit, aynı işsahibi ile gelecekte iş yapmayı düşünüyorsa uyuşmazlık çıkararak o iş bağlantısını kaybetmek yerine o anda uğradığ1 zararı sineye çekmeyi tercih edebilir. Bu örnekten hareketle görüleceği üzere, tacirler, mevcut ticari ilişkilerini korumayı, kısa vadede uğranılan zararın giderilmesine tercih edilebilir. Kısaca, ticari menfaatleri daha fazlaysa, özellikle milletlerarası ticaretin aktörleri, uyuşmazlık çıkarmak yerine zarara katlanmayı tercih edebilirler. Korunan ticari menfaatin değeriyle doğru orantılı olarak fedakârlıkta bulunmaya hazırdırlar. $\mathrm{Bu}$ kapasitedeki aktörler arasında uyuşmazlık, her iki tarafın menfaatini dengeleyen bir çözümün bulunmasının imkânsız olduğunun anlaşıldığı hâllerde doğar. Diğer bir ifadeyle bıçak kemiğe dayandığında taraflar haklarını hukuki çözümlerle aramayı tercih edeceklerdir. Bu aşamadan sonra da arabuluculuk faaliyetine başvurulmasının ve bir de arabulucunun katılımıyla tarafların ticari menfaatlerini tekrar değerlendirmelerinin ve arabulucunun teşvikleri sayesinde kabul edebilecekleri bir çözüme ulaşmalarının ancak nadiren gerçekleşebileceği kanaatindeyiz. Dolayısıyla, ticari menfaatlerini doğru analiz edebilen ticari aktörler için arabuluculuk faaliyetinin tahkimin bir ön şartı olarak kabul edilmesinin faydadan ziyade âdeta kanlı bıçaklı tarafların tahkim yargılamasını geciktirmek ve güçleştirmek için daha fazla imkâna sahip olmalarına hizmet ettiği kanaatindeyiz ${ }^{51}$. Örneğin, Dubai Milletlerarası Tahkim Merkezi Tahkim Kurallarına tabi olarak 2019 yılı itibariyle görülmekte olan üç ayrı derdest tahkim yargılamasına konu olan uyuşmazlıkta tahkim öncesi çözüm yoluna başvurulmadığı için yetki itirazında bulunan taraf olarak iş sahibi, yüklenicinin uyuşmazlığın müzakere yoluyla çözülmesi için randevu talebine cevap dahi vermemiştir.

Nitekim, arabuluculuğun uyuşmazlık çözüm yöntemi olarak kayda değer bir ağırlığa sahip olduğu ABD'de dahi, tarafların sözleşmede kararlaştırılmış olması veya hâkimin kararı nedeniyle öncelikle arabuluculuk yoluna başvurduklarında, gerçekten kendi iradelerinin bir sonucu olarak arabuluculuk yoluna başvurmadıkları için arabuluculuk aşamasının başarılı olmadığını gösteren tecrübeler de bulunmaktadır. Arabulucu-Tahkim Yolunun, ancak ve ancak tarafların uyuşmazlıklarını, samimi bir şekilde arabuluculuk yoluyla çözmek konusunda istekli olmaları hâlinde başarılı

\footnotetext{
50 Fullerton 32.

${ }^{51}$ Arabuluculuk yolunun bu amaçla da kullanıldığı ifade edilmiştir. Bkz Stipanowıch, Yang, Welsh, Qiming, Robinson, Jinghui, Guang, Kichaven, Madigan, Hongsong, Jianhua 412.
} 
olabileceğı belirtilmektedir. Buradan hareketle, kanun gereği veya hâkimin kararı sonucunda arabuluculuk yoluna başvurulması hâlinde arabuluculuğun beklendiği kadar başarılı olamayacăğ sonucuna varılmaktadır ${ }^{52}$.

Buna karşılık başka bir kategori ticari aktör ise ticari menfaatlerini doğru değerlendiremeyebilir. Bu kategoridekiler, biraz fedakârlıkla ticari olarak daha lehlerine bir sonuç elde etmeye konsantre olmak yerine karşı taraftan mümkün olduğunca çok tazminat vb. almak ister. $\mathrm{Bu}$ tür ilişkilerde, arabulucu, tarafları makul davranmaya teşvik edebilir ve taraflar kısa vadeli menfaatleri yerine kendileri için ticari olarak daha başarılı ve/veya daha barışçıl çözümler üreterek uyuşmazlığa son verebilirler. Bu nitelikteki taraflar için arabuluculuğun yargilama öncesinde tüketilmesi gereken bir yol olması uyuşmazlıkların sulh yoluyla çözülmesinde etkili olabilir.

Arabuluculuk Tahkim Yolunun başarısında tarafların milliyetlerinin önemli olup olmadığına ilişkin tartışmalar yapılmıştır. Arap ya da Uzak Asya milliyetlerine mensup kişilerin, örneğin Japonya, arabuluculuk yoluyla uzlaşmaya Avrupa ve Kuzey Amerika ülkelerinin milliyetlerine mensup kişilerden daha yatkın olduklarına ilişkin görüşler ileri sürülmüsstür. Haklı olarak, milletlerarası ticaretin aktörleri incelendiğinde milliyetlerine dayalı olarak ayrım yapılamayacağ 1 ifade edilmiştir. Gerçekten, birçok şirketin yöneticisi şirket ya da hissedarlarının tabiiyetinde olduğu devletin kültüründe yetişmemiş olabilir. Bazı şirketlerin ortaklarının örneğin Birleşik Arap Emirlikleri tabiiyetinde olmalarına rağmen yöneticilerinin, örneğin Avusturalyalı ya da Hindistan vatandaşı olduklarını gözlemliyoruz. Bu durumda, bu şirketin dahil olduğu uyuşmazlıklarda nasıl bir kültürel yaklaşımı olacağını bilemeyebiliriz. Benzer şekilde, ABD'nde eğitim görmüş ve orada çalışmış bir Türk vatandaşı tarafından yönetilen bir şirket tarafindan alternatif uyuşmazlık çözüm yöntemlerine ne şekilde yaklaşılacağını bilemeyiz. Bu nedenle tarafların mensubu oldukları milliyetten hareketle alternatif uyuşmazlık çözüm yöntemlerine yaklaşımları konusunda genelleme yapmaktan kaçınılması uygun olur ${ }^{53}$.

Yukarıdaki açıklamalarımızdan ${ }^{54}$ görüldüğü gibi, davalının arabuluculuk faaliyetine başvurulmaması nedeniyle yargılamaya devam edilemeyeceği yönündeki itirazları ile karşılaşan hakemler, davalının iddiaları hakkında tarafların iddia ve savunmalarını değerlendirerek bir karar vermek zorundadır. Bu halde yargılamanın uzaması ve yargılama giderlerinin artması âdeta kaçınılmazdır. Bu sebeple, taraflar arasında uyuşmazlık çözüm anlaşması henüz müzakere edilirken somut ilişkide arabuluculuk faaliyetinin beklenen faydayı sağlayamayacağı anlaşlabiliyorsa tahkim davasının başlatılmasından önce arabuluculuk faaliyetinin tüketilmesi bir şart olarak yazılmamalıdır.

2 Telford 11; Stipanowıch, Yang, Welsh, Qiming, Robinson, Jinghui, Guang, Kichaven, Madigan, Hongsong, Jianhua 411.

53 Ayrıntılı tartışmalar için bkz.: Tai-Heng Cheng, 'Reflections on Culture in Med-Arb' 2010 34(9-10) NYLS Legal Studies 424 (SSRN: https://ssrn.com/abstract=1574814 or http://dx.doi.org/10.2139/ssrn.1574814, Erişim Tarihi: 11/09/2019).

54 Bkz. Yuk. IV. B. 
$\mathrm{Bu}$ görüş, arabuluculuğu bir uyuşmazlık çözüm yöntemi alternatifi olarak taraflara sunmadığı noktasında eleştirilebilirse de bu eleştirilerin haklı olmayacağı kanaatindeyiz. Taraflar, arabulucuya başvurmak, süreci devam ettirmek, sonuçlandırmak veya bu süreçten vazgeçmek konusunda serbesttirler (HUAK. m3(1)). Uyuşmazlık çözüm anlaşmasında, tahkim yargılamasına başlamadan önce arabuluculuk yoluna başvurulacağı öngörülmemiş olsa bile tahkimden önce veya tahkim yargılaması devam ederken taraflar her zaman arabulucuya başvurabilir. Arabuluculuktan hiç söz edilmeden tahkim anlaşması yapılmış olması, tarafların bir arabulucu yardımıyla uyuşmazlıklarını sulh yoluyla çözme girişimlerine engel değildir" . Zira "taraflar dava açılmadan önce veya davanın görülmesi sırasında arabulucuya başvurma konusunda anlaşabilirler” (HUAK.m13(1)). Taraflar arasında önceden yapılmış bir arabuluculuk anlaşması olmasa bile taraflardan birisi tahkim yargılamasından önce ya da yargılama devam ederken, diğer tarafa arabuluculuğa başvurmayı teklif edebilir (HUAK.m13(2)).

Hukuk Uyuşmazlıklarında Arabuluculuk Kanunu gibi, MTK'da ve HMK'da, tarafların tahkim yargılaması devam ederken arabulucuya başvurmalarına engel olabilecek herhangi bir emredici kanun hükmü bulunmamaktadır. Dolayısıyla, uyuşmazlık çözümü anlaşmasında tahkimden önce arabulucuya başvurulmasına ilişkin bir hükme yer verilmemesi arabulucuya başvurmak isteyen tarafların arabulucuya başvurmalarına engel değildir.

ISTAC Arabuluculuk-Tahkim Kuralları'nın üçüncü maddesi Arabuluculuk -Tahkim anlaşması yapılma zamanını düzenlemekte ve tarafların tahkim yargılamasına başladıktan sonra da arabuluculuk yoluna başvurmak konusunda anlaşabileceklerini ve bu anlaşmanın sonuçlarını açıkça düzenlemektedir ${ }^{56}$.

Tahkim yargılaması başladıktan sonra arabuluculuğa başvurulması hâlinde arabuluculuğun başarısızlıkla sonuçlanması hâlinde arabuluculuk faaliyetinin

\footnotetext{
Bkz.: Tan Dehmen 464.

56 Madde şu şekildedir:

Arabuluculuk-Tahkim Anlaşmasının Yapılma Zamanı

Taraflar, arabuluculuk-tahkim anlaşmasını, aralarında belirlenebilir bir hukukî ilişkiden doğabilecek veya doğmuş bir uyuşmazlığın çözümü için uyuşmazlığın nihaî olarak çözümlenmesine kadar herhangi bir aşamada yapabilirler.

Bu uyuşmazlığın çözümü için daha önce müzakere edilmiş olması, arabuluculuk yöntemine başvurulmuş olması veya tahkim yargılamasının başlatılmış olması, tarafların arabuluculuk-tahkim anlaşması yapmasına engel olmaz.

3. Tarafların, aralarındaki uyuşmazlığın çözümü için arabuluculuk yöntemine başvurduktan sonra İstanbul Tahkim Merkezi Arabuluculuk-Tahkim Kuralları uyarınca arabuluculuk-tahkim anlaşması yapmaları durumunda, arabuluculuk sürecine İstanbul Tahkim Merkezi Arabuluculuk-Tahkim Kuralları uyarınca devam edilir.

4. Tarafların, aralarındaki uyuşmazlığın çözümü için tahkim yargılaması başlattıktan sonra İstanbul Tahkim Merkezi Arabuluculuk-Tahkim Kuralları uyarınca arabuluculuk-tahkim anlaşması yapmaları durumunda, tahkim yargılaması durur ve uyuşmazlık İstanbul Tahkim Merkezi Arabuluculuk- Tahkim Kuralları'na göre çözülür. Uyuşmazlığın, İstanbul Tahkim Merkezi Arabuluculuk-Tahkim Kuralları uyarınca arabuluculuk yöntemi ile çözümlenememesi durumunda, durmuş olan tahkim yargılamasına İstanbul Tahkim Merkezi Arabuluculuk-Tahkim Kuralları uyarınca aynı hakem kurulu ile kalınan yargılama aşamasından devam edilir. Eğer daha önce durmuş olan tahkim yargılamasına İstanbul Tahkim Merkezi Arabuluculuk-Tahkim Kuralları uyarınca devam edilmesi tahkim yeri hukuku kuralları, İstanbul Tahkim Merkezi Arabuluculuk-Tahkim Kuralları, İstanbul Tahkim Merkezi Tahkim Kuralları veya hakkaniyet kurallarıyla çelişkili durumlar yaratacak ise, taraflardan birinin yazılı talebi üzerine Divan'ın vereceği kararla daha önce durmuş olan tahkim yargılamasına devam edilmemesine ve İstanbul Tahkim Merkezi Arabuluculuk-Tahkim Kuralları uyarınca yeni bir tahkim davası açılmasına karar verilebilir.
} 
tahkim sürecine zarar vereceğine veya tarafların iddia ve savunmalarını olumsuz etkileyebileceğine ilişkin bazı haklı kaygılar olabilir. Bu kaygılardan bir tanesi, tahkim yargılaması devam ederken arabulucuya başvurulması hâlinde henüz bir sonuç alınmadan tahkim süresinin önemli ölçüde tükenmesi hatta sona ermesi olabilir. $\mathrm{Bu}$ kaygıyı bertaraf etmenin yolu, tarafların tahkim yargilaması devam ederken arabuluculuğa başvurmak konusunda anlaşma yaparlarken arabuluculuk faaliyetinin tahkim süresine etkisi konusunda da anlaşma yapmalarıdır.

\section{Arabuluculuk Faaliyetinin Başarısızlıkla Sonuçlanması Hâlinde Arabuluculuk Faaliyeti ve Müteakip Tahkim Yargılaması Arasındaki İlişki}

Taraflar öncelikle arabulucuya başvurmuş, arabuluculuk faaliyeti gerçekleşmiş ama uyuşmazlık çözümlenememiş olabilir. Bu durumda aynı taraflar, uyuşmazlıklarını çözümleyebilmek için tahkim yargılaması başlatacaklardır. Bu ihtimalde birçok farklı sorun ve soru ile karşılaşılabilir. Aşağıda bunlara değinilecektir.

\section{A. Arabulucunun Tahkim Aşamasında Hakem Olması}

Arabulucuya başvuran ancak uyuşmazlıklarını arabuluculuk faaliyeti sonucunda çözemeyen taraflar, arabulucu olarak görev yapan kişinin hakem olarak da görev yapmasını isteyebilir.

Arabulucunun hakem olarak görev yapmasının gerçekten faydalı mı olduğu yoksa kendi içinde önemli tehlikeler mi içerdiği oldukça tartışmalı bir konudur. Nitekim ABD'de bazı uygulamacilar bu arabulucunun hakem sifatıyla yargılamaya devam etmesini önerirken çok sayıda kişi de bu uyuşmazlık yönteminin isabetli olmadı̆̆ını savunmaktadir ${ }^{57}$.

Aşağıda, arabulucunun hakem olarak görev yapmasının hukuki dayanağı, faydaları ve riskli yönleriyle, arabulucunun hakem olarak görev yapmasının neden olduğu risklerin bertaraf edilmesinin mümkün olup olmadığı tartışılacaktır.

\section{Arabulucunun Tahkimde Hakem Olarak Görev Yapmasının Yasal Dayanağı}

Hakemler görevi kabul etmeden önce bağımsız ve tarafsız olmalı ve yargılamanın sonuna kadar bağımsız ve tarafsız kalmalıdır. Hakem olarak atanan kişiler, tarafsızlıklarından şüphe edilmesini gerektirecek hâl ve şartların varlığı hâlinde, bu hususta tarafları bilgilendirmek zorundadır (MTK.m7, HMK.m417) ${ }^{58}$.

MTK' da ve HMK' da, arabulucuların hakem olarak görev yapmalarını yasaklayan bir düzenleme yoktur. HUAK da arabulucunun hakem olarak görev yapmasina

\footnotetext{
Fullerton 37.

58 Bu konuda ayrıntılı bilgi için bkz.: Süheyla Balkar Bozkurt, Milletleri Ticari Tahkimde Hakemlerin Bağımsızlık Yükümlülüğ̈̈ (1st On İki Levha 2016).
} 
ilişkin bir düzenleme yapılmamıştır. HUAK, arabulucunun "bu sıfatla görev yaptı̆̆ uyuşmazlıkla ilgili olarak açılan davada, daha sonra taraflardan birinin avukatı olarak görev üstlenmesini” yasaklamıştır (HUAK.m9(4)). ${ }^{59} 2018$ y1lında yürürlüğe giren HUAK Yönetmeliği'nde arabulucunun avukat olması yasaklanmıştır ${ }^{60}$.

Arabuluculuk Etik Kurallarının, menfaat ilişkisi veya çatışması kenar başlıklı 4üncü maddesinin 61ncı fikrasında arabulucunun hakem olarak görev yapması hususu düzenlenmektedir. Buna göre "Arabulucu, bu sıfatla görev yaptlğı uyuşmazllk ile ilgili olarak açılan davada, daha sonra, avukat olarak görev üstlenemez. Ancak, taraflar açı ve yazılı onayları ile birlikte talep ederlerse, açılan tahkim yargılamasında hakemlik yapabilir. ${ }^{61}$ "

Görüldügü gibi, Türkiye'de arabulucu ancak tarafların açık ve yazılı onaylarının bulunması koşuluyla tahkim aşamasında hakem olarak görev yapabilir.

ISTAC Arabuluculuk - Tahkim Kuralları'nın 5inci maddesinde “arabuluculuktahkim veya arabuluculuk süreçlerinde arabulucu olarak görev yapan kişi, tarafların açık ve yazılı onayı olmaksızın, aynı uyuşmazlık hakkındaki tahkim yargılamasında hakem olarak görev yapamaz." denilmek suretiyle arabulucunun hakem olarak görev yapması tarafların açık ve yazılı onayının alınması şartına bağlanmıştır.

\section{Arabulucunun Hakem Olarak Görev Yapmasının Faydaları}

Arabulucunun hakem olarak görev yapmasının birçok faydası dile getirilmiştir. Bunlar aşağıdaki şekilde özetlenebilir.

Arabuluculuk faaliyeti sırasında, arabulucu, uyuşmazlık, tarafların iddia ve savunmaları konusunda bilgi edinmişse arabulucunun bu bilgileri, tahkim yargılamasında daha hızlı ve az masrafla karar verilmesine yardımcı olabilir ${ }^{62}$.

Arabulucunun hakem olarak da görev yapacağını bilen taraflar uyuşmazlığı arabuluculuk aşamasında çözmek konusunda istekli davranabilirler ${ }^{63}$. Kuzey Amerika'da, arabulucunun hakem olacağını bilen tarafların arabuluculuk sırasında daha yapıcı ve barışçıl davrandıkları, daha çok sulh alternatifleri yarattıkları ve arabuluculuk aşamasının daha başarılı olduğu gözlenmiştir ${ }^{64}$.

\footnotetext{
59 Buna karşılık, mülga HUAK Yönetmeliği’nin 12(4) hükmü arabulucunun ilgili uyuşmazlığa ilişkin açılan davada hâkim, hakem ya da bilirkişi olmasını yasaklamıştı. 26.01.2013 tarihli Resmi Gazete'de yayımlanan mülga HUAK Yönetmeliği m. 12(4): “Arabulucu, bu sıfatla görev yaptı̆̆ uyuşmazlık ile ilgili olarak açılan davada, daha sonra, hâkimlik, hakemlik ve bilirkişilik yapamayacağ̀ gibi avukat olarak da görev üstlenemez. ” Mülga Yönetmelik hükmüne yönelik eleştiri için bkz.: Özbek 81 ff.

${ }^{60}$ Hukuk Uyuşmazlıklarında Arabuluculuk Kanunu Yönetmeliği RG. 02.06.2018/30439.

${ }_{61}$ http://www.adb.adalet.gov.tr/Sayfalar/Teskilat/mevzuat/etik_kurallar.html (Erişim Tarihi 22/09/2019)

${ }_{62}$ Ildır 100; Özbek 21; Berkhan 25 ff; Brian 159; Bu yönde bkz: Stipanowıch, Yang, Welsh, Qiming, Robinson, Jinghui, Guang, Kichaven, Madigan, Hongsong, Jianhua 399; Telford 2; Sussman 73.

63 Ibid 102.

64 Telford $3 \mathrm{ff}$.
} 
Arabulucunun ileride hakem olması hâlinde daha doğru bir karar vereceği de ifade edilen faydaları arasındadır. Zira hakem arabuluculuk aşamasında uyuşmazlıkla ilgili pek çok şeyi -hatta gizli kalması tercih edilen bilgileri de öğrenmiştir. Bu durumda hakem tarafların kolaylıkla kabul edebilecekleri hatta tarafların bu şekilde dahi sulh olabilecekleri bir karar verebilir ${ }^{65}$.

Diğer bir fayda da arabuluculuk aşamasında taraflar aralarındaki birden çok uyuşmazlıktan önemli bir kısmı üzerinde anlaşma sağlanabilir. Böylece daha az sayıda uyuşmazlık hakeme havale edilebilir ${ }^{66}$.

Arabuluculuk aşamasında arabulucuya sunulan bilgiler ve tartışmalar sayesinde, taraflar müstakbel hakem kararını öngörebilir ${ }^{67}$.

\section{Arabulucunun Hakem Olarak Görev Yapmasının Riskleri}

Arabulucunun hakem olarak görev yapmasının, yukarıda sayılan faydaları yanında üç temel riskinden söz edilmektedir.

Bunlardan ilki, arabuluculuk sürecinde uyuşmazlık ve taraflar hakkında edindiği bilgiler nedeniyle arabulucunun tahkimde tarafsiz hareket edememesidir.

İkincisi, tarafların arabulucuyla birebir oturumlarda arabulucuyla paylaştığ1 - diğer taraftan- gizli bilgilerin tahkim aşamasında hakemin kararını etkilemesidir. Tarafların arabulucuya aktardıkları gizli bilgiler arabulucu-hakem tarafindan kendilerine karşı kullanılabilir ya da diğer tarafın hakkında beyanda bulunma imkânına sahip olmadıkları bilgilere dayanarak arabulucu hakem karar verebilir.

Üçüncüsü ise, arabulucu-hakemin taraflar üzerinde sahip olduğu gücün arabulucu tarafından kötüye kullanılması ihtimalidir. Arabuluculuk aşamasının başarısızlıkla sonuçlanması hâlinde hakem olarak görev yapacak arabulucunun arabuluculuk aşamasında uygun gördüğü çözümü taraflara dayatma gücüne sahip olabilmesidir. Böylece taraflar benimsemedikleri bir çözüm üzerinde sulh olabilirler zira arabuluculuk aşaması başarısız olursa arabulucunun önerdiği çözüme paralel bir hakem kararı verileceğini düşünebilirler ${ }^{68}$.

Diğer bir risk ise, arabulucunun hakem olarak da görev alacak olacağı için bir an evvel tahkime başlamak konusunda istekli olması nedeniyle uyuşmazlığın arabuluculuk aşamasında çözülebilmesi için yeterli çabayı sarf etmemesidir ${ }^{69}$. $\mathrm{Bu}$ durumda, Arabuluculuk-Tahkim yolundan beklenen uyuşmazlığın tahkime

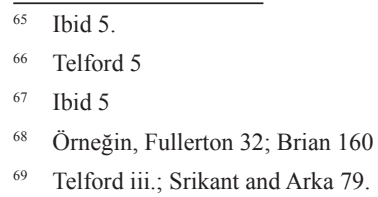


başvurmaksızın arabuluculuk aşamasında daha hızlı ve ucuza çözülmesi beklentisi gerçekleşmeyebilir.

Aşağıda bu riskler ayrıntılı olarak ele alınacaktır.

\section{a. Arabulucunun Tahkim Aşamasında Tarafsız Davranamaması Riski}

Arabulucuların da tıpkı hakemler ve hâkimler gibi tarafsız olması gerekir ${ }^{70}$. Arabuluculuk aşamasında arabulucu, taraflar ve uyuşmazlık hakkında birçok şey öğrenmiş olabilir. Sahip olduğu bu bilgiler ve edindiği izlenimler, arabulucunun tarafsız bir hakem olarak yargılama yapmasını engelleyebilir ${ }^{71}$. Zira arabulucu, bu bilgiler sonucunda -kendisi bile farkında olmadan- ${ }^{72}$, bazı önyarg1lara sahip olabilir. Arabuluculuk aşmasında arabulucunun uyuşmazlığın çözümü hakkında bir kanaate sahip olması hakem olarak görev aldığında tarafsızlığını tehdit eden bir durumdur. Örneğin, taraflar, genellikle sulh olmak için talep sonuçlarından daha azına razı olabilirler. Ancak, hakemin kararını etkilememesi için bu bilgiyi hakemle paylaşmayacaklardır ${ }^{73}$. Davacı, arabuluculuk faaliyeti sırasında örneğin tahkimde talep edeceği tazminatın yarısının ödenmesine razı olmuşsa, arabuluculuk yapmış olan hakem, tahkim yargılamasında davacı hukuken haklı olsa ve alacağının tamamını ispatlayabilse bile tazminatın tamamına hükmederken çekimser davranabilir zira davacının aslında razı olduğu bir paranın iki katına hükmettiğini düşünebilir ${ }^{74}$.

Tarafların gözünde hakemin tarafsızlığını etkileyecek diğer bir durum da arabuluculuk aşamasında uygulanan taktiklere bağlı olarak arabulucunun hakemin uyuşmazlığın çözümü hakkındaki görüşlerini taraflara söylemesidir. Arabulucunun, arabuluculuk sürecinde başvuracağı birçok teknik vardır. Bu tekniklerden bazıları arabulucunun daha aktif bir rol alıp uyuşmazlık hakkındaki kendi fikirlerini taraflarla

\footnotetext{
70 $\quad$ Ildır 50 ff; Arabulucunun tarafsızlığı hakkında bkz: Berkhan 29.

Türkiye Arabuluculuk Etik Kurallarında arabulucunun bağımsızlığı 3üncü maddede düzenlenmiştir:

(1) Tarafsılık, arabulucunun taraf tutmamasını ve taraflar hakkında önyargılı olmamasını kapsar.

(2) Arabulucu, taraflardan birinin kişiliğine, geçmişine, inanç ve değerlerine ve arabuluculuk sürecindeki tutum ve davranışlarına veya başka bir sebebe dayanarak taraf tutmamalı ve önyargılı davranmamalıdır.

(3) Arabulucu, arabuluculuk sürecini yürütürken tarafsız olmak ve tarafsızlığını şüpheli hâle getirecek davranışlardan kaçınmak zorundadır. Arabulucu, kendisinin davranış ve görünüşteki tarafsızlığından şüphe duyulmasına yol açacak şekilde, taraflara değerli bir hediye, yardım, borç veya değerli başka bir mal vermemeli ve onlardan da kabul etmemelidir. (4) Arabulucu, arabuluculuğu tarafsız bir şekilde yönetemeyecek ise arabulucu olma teklifini reddetmeli ve hangi aşamada olursa olsun arabuluculuktan çekilmelidir.

(5) Arabulucunun tarafsızlığından şüphe edilmesini gerektirecek önemli hâl ve şartların varlığının söz konusu olması veya sonradan ortaya çıkması hâlinde, bu hususta tarafları bilgilendirmesine rağmen, taraflar, arabulucudan görevi üstlenmesini birlikte talep ederlerse, arabulucu bu görevi üstlenebilir veya üstlenmiş olduğu görevi sürdürebilir.

(6) Arabulucu, taraflarca aksi kararlaştırılmadıkça, arabuluculuk sürecini arabuluculuğa uygun tarafsız bir yerde yürütmelidir. (http://www.adb.adalet.gov.tr/Sayfalar/Teskilat/mevzuat/etik_kurallar.html Erişim Tarihi 22/09/19)

71 Nitekim mülga Yönetmeliğin 12(4) hükmünde arabulucunun hakem olarak görev yapmasının yasaklanmasının nedeni hakemin tarafsızlığını sağlamak olduğu ifade edilmiştir. Bkz.: Özbek 15; aynı yönde Brian 202; Berkhan 26.

72 Regina v. Gough (1993) 2 All Er 724 kararında bir kişinin tarafsız olduğunu düşünse bile tarafsız olmamasının mümkün olduğunu ifade etmiştir. Srikant and Arka 96.

73 Brian 173; Stipanowich, Yang, Welsh, Qiming, Robinson, Jinghui, Guang, Kichaven, Madigan, Hongsong, Jianhua 401; Telford 4.

74 Aynı yönde bkz.: Brian 180; Baril, Dickey 6.
} 
paylaşmasını gerektirir. Böylece, taraflar müstakbel hakemin uyuşmazlığa yaklaşımı hakkındaki fikirlerini öğrenebilir ya da tahmin edebilirler ${ }^{75}$. Örneğin, arabulucu, bir tarafın talep ettiği tazminat tutarını fahiş bulduğunu ya da zararın ispatlanamayacağını söyleyebilir. Böyle bir açıklamanın yapılmış olması, tahkim aşamasında, tarafların gözünde hakemin tarafsızlığına gölge düşürebilir.

Arabulucunun ilk önce arabuluculuk sürecine katılmış olmasının hakemin tarafsızlığına etkisine ilişkin Uluslararası Barolar Birliği’nin ve ABD'deki bazı düzenlemelere değinmek uygun olur.

Uluslararası Barolar Birliği'nin Menfaat Çatışmalarına İlişkin Kılavuzunun (2)(a) paragrafinda bir hakem tahkim başlamadan önce ya da tahkim yargılaması devam ederken kendisinin tarafsızlığı ve bağımsızlığ 1 konusunda şüpheye kapılırsa hakem olarak görev yapmamalıdır. Hakemin bağımsızlığı ve tarafsızlığından şüphe duyulmasını haklı gösterecek sebep olsa bile taraflar hakemi reddetme haklarından feragat edebilir (Kılavuz (4)(a)). Hakem olarak görev alan kişi, daha önce taraflar arasındaki uzlaştırma, arabuluculuk gibi sulh görüşmelerinde görev almış olabilir. Bu hallerde, arabulucu-hakem, arabuluculuk görevini üstlenmeden önce hakem olarak görev alabileceği ve tarafların hakemin tarafsız olmadığına ilişkin itiraz etmeyecekleri konusunda anlaşmasını sağlamalıdır. Tarafların anlaşmaları, hakemin arabuluculuk sürecine katılmış olması ve o aşamada edindiği bilgiler nedeniyle tahkimde hakemin reddi hakkından feragat etmeleri anlamına gelecektir. Arabuluculuk süreci başarıyla sonuçlanmazsa taraflar bu anlaşmalarıyla bağlıdır. Ancak, hakem bizzat kendisi sulh görüşmelerine katılması ve o aşamada öğrendikleri nedeniyle tarafsızlığından şüphe duyarsa hakem olarak görev yapmamalıdır (Kılavuz (4)(d)).

Kılavuz, hakemin dostane çözüm usullerinde görev almasını, hakemin tarafsızlığından şüphe duyulmasını objektif olarak haklı gösteren bir sebep olarak değerlendirmektedir. Ancak, tarafların rızasıyla hakemlik görevinin yapılmasına izin vermektedir. Bununla birlikte taraflar rıza gösterseler bile hakem bizzat kendisi kendi tarafsızlığından şüpheye düşerse görevi kabul etmemesi tavsiye edilmektedir.

Amerikan Tahkim Birliği, Amerikan Barolar Birliği ve Uyuşmazlık Çözüm Birliği tarafında 2005 yılında onaylanan arabuluculuk sürecine hâkim ilkeleri düzenleyen kurallar da Uluslararası Barolar Birliğiyle benzer bir yaklaşım sergilemektedir. Standart VI 8inci paragrafta, arabulucuların aynı taraflar arasında aynı uyuşmazlıkla ilgili olarak tarafların rızası olmadıkça başka bir görev alamayacağı düzenlemiştir. Görevi kabul etmeden önce, arabulucu, hakem olmasının sonuçları konusunda tarafları aydınlatması ve bu sonuçların taraflarca kabul edilmesi hâlinde görevi kabul edebilir ${ }^{76}$.

\footnotetext{
Brian 173; Stipanowich, Yang, Welsh, Qiming, Robinson, Jinghui, Guang, Kichaven, Madigan, Hongsong, Jianhua 401; Telford 4.

76 https://www.americanbar.org/content/dam/aba/migrated/2011_build/dispute_resolution/model_standards_conduct_ april2007.authcheckdam.pdf (Erişim Tarihi 14/09/2019)
} 
Bir Amerikan mahkeme kararı olan Gaskin vs. Gaskin ${ }^{77}$ kararında, mahkeme, arabulucunun aynı ya da ilgili başka bir uyuşmazlıkta hakem olmasına tarafların açık muvafakatleri yoksa arabulucunun hakem olarak görev yapamayacağına karar vermiştii ${ }^{78}$.

Yukarıda değindiğimiz Türkiye'deki Arabuluculuk Etik Kuralları ${ }^{79}$, uluslararası kurallarla uyumludur. Ancak, tarafların, arabulucunun hakem olmasına riza göstermeleri tarafların arabulucunun hakem olmasının yarattığ 1 risklerin farkında olmalarını gerektirmektedir ki tarafların bu konuda yeterince bilgili ve bilinçli olmaları her zaman mümkün olmayabilir ${ }^{80}$.

\section{b. Arabuluculuk Esnasında Arabulucu Tarafından Öğrenilen Gizli Bilgilerin Hakem Kararını Etkilemesi}

Yukarıda ifade ettiğimiz gibi, arabulucunun kullanacağı birçok teknik vardır. $\mathrm{Bu}$ tekniklerden bir tanesi de arabulucunun taraflarla hep birlikte yapilan oturumlar dişında her bir tarafla diğer tarafin hazır bulunmadı̆̆ düzenlenmesidir ${ }^{81}$. Türkiye Arabuluculuk Etik Kuralları'nın 6ncı maddesinin üçüncü fikrası uyarınca, arabuluculuk sürecinde taraflardan biriyle özel oturumda bir araya gelen arabulucu, bu özel oturumda edindiği hiçbir bilgiyi, bilgiyi veren tarafın rızası olmadan, doğrudan veya dolaylı olarak diğer tarafa aktarmamalıdır ${ }^{82}$. Arabulucu, bu bilgileri diğer tarafa uyuşmazlığın sulh yoluyla çözülmesini temin etmek amacıyla kullanmalıdır ${ }^{83}$. Ancak burada dikkat edilmesi gereken nokta, karşı tarafın, arabulucuya aktarılan gizli bilgilerden bihaber olması ve hâliyle, bu bilgilere karşı beyanda bulunma imkânına sahip olmamasıdır. Oysa gizli oturumlarda nihai hakem kararını etkilemek amacıyla gerçek dışı bilgiler verilmesi ihtimali vardır. Bu gizli diyebileceğimiz bilgiler, arabuluculuğun başarısız olması hâlinde hakem kararını etkileyebilir ${ }^{84}$. ABD'de yapılan araştırmalar bu yönde sonuçlar vermiştir ${ }^{85}$. Hatta bu durum hakem kararının iptaline dahi neden olabilir ${ }^{86}$.

Arabulucuya aktarılan bilgilerin hakem kararını etkilemesi riskini ciddi bir risk olarak değerlendiren ve arabulucu olarak katıldıkları uyuşmazlıklarda hakemlik yapmayı reddedenler olduğu gibi deneyimli arabulucu-hakemlerle sürecin yürütülmesi hâlinde böyle bir risk olmadığını savunanlar da bulunmaktadır ${ }^{87}$. ABD'de

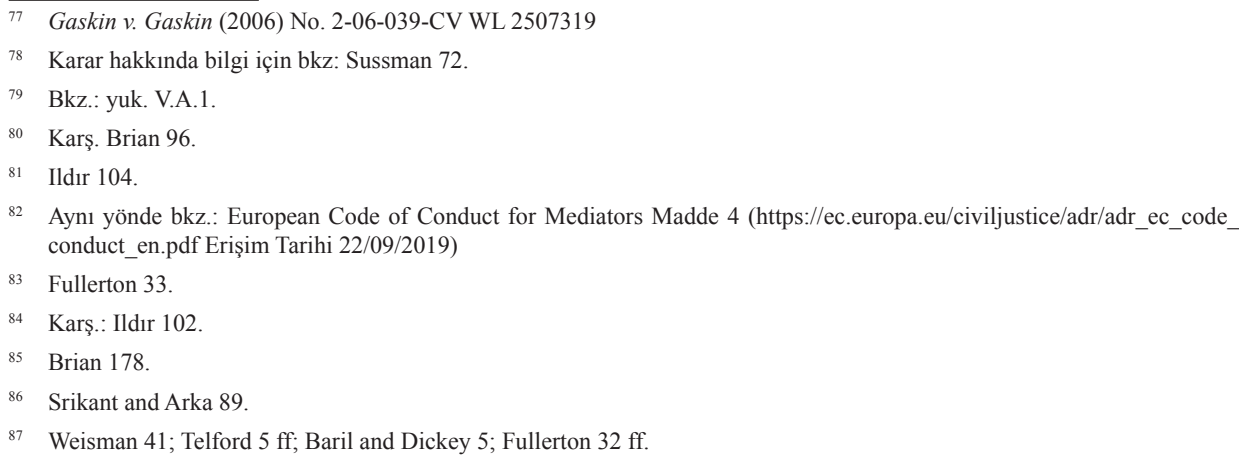


ve Kanada'da arabulucu-hakem olarak görev yapan kişilerin bu konuda bir sorun yaşamadıkları ve konunun abartıldığını söyledikleri iddia edilmiştir ${ }^{88}$. Buna karşılık kişisel deneyimlerine dayanarak arabuluculuktan tahkime geçişin zor olduğunu ifade edenler de bulunmaktadir ${ }^{89}$.

Böyle bir risk olmadığını savunan yazarlara göre, arabuluculuk aşamasından tahkime devam edilmesi hâlinde arabulucu-hakem sanki hiç arabuluculuk süreci yaşanmamış gibi davranabilir ki davranmalıdır da ${ }^{90}$. Gizli bilgilerin öğrenilmesinin herhangi bir risk yaratmadığını iddia edenler, bu görüşlerine dayanak olarak ABD' de hâkimlerin gördükleri bir delilin taraflarca davada delil olarak kullanılmasına izin verilmediğinde, hâkimlerin delili öğrenmelerine rağmen bunu göz ard1 edebildiklerini, âdeta geçici bir hafiza kaybı yaşayabilmelerini göstermektedir ${ }^{91}$.

Arabulucu-hakemin, tahkim yargılamasının başında taraflara kendisinin bir insan olduğunu ve beyninin bazı bilgileri hatırlayacağını ancak bunları göz ardı etmek için elinden geleni yapacağını söylemesinin yeterli olduğu da iddia edilmiştir ${ }^{92}$. Fakat psikolojik araştırmalar, kişilerin bildikleri bir şeyi bilinçli olarak bilmiyormuş gibi davranmalarının oldukça zor olduğunu göstermiştir ${ }^{93}$.

Tarafların gözündeki, arabuluculuk aşamasında paylaşılan bilgilerin hakem kararını etkilemesi riski, tahkim yargılamasına değil, bilakis, arabuluculuk sürecine zarar verebilir. Arabulucuya aktarılan gizli bilgilerin açıklanması riskini değerlendiren ve arabuluculuk sırasında öğrenilen gizli bilgilerin hakemin kararını etkileyebileceğini düşünen taraflar, tahkim aşamasında aleyhlerine kullanılabileceğini düşündüğü bilgileri arabulucuya söylemeyebilir, yeterince açık sözlü ve samimi davranmayabilirler. Oysa arabuluculuğun başarılı olabilmesinin koşullarından birisi, tarafların söylediklerinin ilerideki yargılamada aleyhlerine kullanılabileceğine ilişkin bir kaygı duymaksızın samimi görüşlerini açıklayabilmelerdir ${ }^{94}$. Dolayısıyla aynı arabulucunun hakem olarak görev alacak olması, arabuluculuktan beklenen faydayı ortadan kaldırabilir ve arabuluculuk süreci bir zaman kaybına dönüşebilir ${ }^{95}$.

Diğer bir ihtimal ise tarafların arabuluculuk aşamasını tahkime bir hazırlık gibi değerlendirmeleri ve stratejilerini buna göre belirlemeleri hatta arabulucunun sempatisini kazanmak amaciyla hareket etmeleridir ${ }^{96}$. Nitekim ABD'de yapılan 
araştırma sonuçları bu hakikati teyit etmiştir ${ }^{97}$. Böylece, arabuluculuk aşaması uyuşmazlığın sulhen çözülmesine hizmet etmeyebilir.

\section{c. Tarafların İstemedikleri Bir Sulhe Zorlanmaları}

Arabuluculukta tarafların kendi kararlarını verebilme hakları vardır. $\mathrm{Bu}$ hak, Türkiye Arabuluculuk Etik Kurallarının ikinci maddesinde düzenlenmiştir. Buna göre, tarafların "kendi kararını verme hakkl, tarafların sürece başlamadan, süreç içerisinde ve sonuç aşamasında özgür ve aydınlanmış iradeleriyle, gönüllü ve baskı altında kalmadan karar vermelerini kapsar". Bu madde uyarınca, "arabulucu, hazırlık aşaması veya ilk arabuluculuk toplantısında kendisinin arabuluculuk sürecindeki rolü hakkında taraflara bilgi vermek zorundadır. Arabulucu karar verme yetkisinin kendisinde değil, taraflarda olduğu hususunu vurgulamalıdır".

Arabulucu-hakem, arabuluculuk aşamasının başarısız olması hâlinde tahkim aşamasında uyuşmazlık hakkında nihai karar verecek kişi olacaktır. Arabulucunun, tarafların müzakerelerini kolaylaştıran kişinin ötesinde nihai kararı da verecek kişi olması, arabulucuya tarafların nezdinde önemli bir güç kazandırabilir. Hatta, arabulucu bizzat kendisi bu gücünü kullanarak tarafları kendi önerdiği şekilde bir sulh olmaya zorlayabilir. Bu nedenle, taraflar, arabulucunun bir çözüm önermesi hâlinde uyuşmazlık sulhen çözülmezse bu öneriye paralel bir hakem kararı verileceğini düşünerek aslında benimsemeseler bile arabulucunun önerisini kabul edip sulh olabilir. Böylece, arabuluculuğun tarafların birlikte geliştirdikleri ve her iki tarafın da benimseyeceği şekilde uyuşmazlığın çözülmesi amacı zarar görür ${ }^{98}$.

Karşılaştırmalı hukukta, arabulucuların tarafları sulhe zorlayan teknikler kullanıp kullanmadıkları, tarafların tahkime başvurmaktansa arabulucunun önerdiği çözümü -istemeyerek de olsa- kabul edip etmedikleri araştırılmıştır. Türkiye dışında yapılan araştırmalarda, arabulucu-hakem olarak görev yapan kişilerin bir kısmına yönelik yapılan araştırmalar, tarafların üzerinde böyle bir baskı kuracak yöntemleri kullanmadıkları sonucuna varılmıştır ${ }^{99}$. Ancak, bu araştırmaların Türkiye'de yapılmadı̆̆ı dikkate alınacak olursa benzer saha çalışmaları Türkiye'deki yapılmadığı sürece Türkiye'deki uygulama hakkında kesin bir sonuca varılmaması gerektiği kanaatindeyiz.

\section{Arabulucunun Hakem Olarak Görev Yapmasının Sakıncalarını Gidermek Amacıyla Önerilen Çözümler}

Arabuluculuk ve Tahkim Yolunun yukarıda anlatılan sakıncaları konuyu gündeme getiren hemen herkes tarafindan ifade edilmektedir. Arabuluculuk ve Tahkim Yolunu savunan yazarlar, bu sakıncaları gidermek için çeşitli çözümler önermektedirler.

\footnotetext{
Brian 72; Stipanowıch, Yang, Welsh, Qiming, Robinson, Jinghui, Guang, Kichaven, Madigan, Hongsong, Jianhuas 404.

98 Ildır 102.

99 Telford 10.
} 
$\mathrm{Bu}$ çözümlerin, bir üst başlıkta açıkladığımız risklerin tamamını bertaraf etmesinin mümkün olup olmadığı değerlendirilmelidir.

Arabulucu-hakemin, arabuluculuk aşamasında edindiği bilgilerin tahkimde kullanılmasına ilişkin riski gidermek için, arabulucu-hakemin, arabuluculuk sürecinin hemen başında tahkime devam edilmesi hâlinde gizli bilgiler öğrenirse bunları nasıl ele alacağının taraflara açıklamasının yeterli olduğu ifade edilmiştir ${ }^{100}$. $\mathrm{Bu}$ açıklamanın tarafların aklındaki kaygıları gidermek için yeterli olup olmadığı kanımızca tartışmalıdır.

Diğer bir çözüm yolu önerisi, arabulucunun, taraflarla birebir görüşmeler sonucunda gizli bilgiler öğrenmesi hâlinde hakem kararını etkileyebilecek nitelikteki gizli bilgileri tahkimden önce her iki tarafa da açıklaması zorunluluğu getirilmesidir. $\mathrm{Bu}$ çözüm yolu, Singapur ve Hong Kong hukuklarında benimsenmiştir. Fakat bu çözüm yolu birtakım sorunları barındırmaktadır. Öncelikle, hangi bilgilerin davanın sonucuna etkili olduğunun ve açıklanması gerektiğinin nasıl tespit edileceği belirsizdir. $\mathrm{Bu}$ nedenle, birebir görüşmelerde öğrenilen bilgilerin tamamının tahkimden önce taraflara açıklanması önerilmiştir ${ }^{101}$. Bu çözümün zayıf tarafı, gizli bilgilerin, uyuşmazlığın diğer tarafına açıklanacağını bilen tarafların gizli bilgeleri arabulucuya vermek istememeleri ihtimalidir ${ }^{102}$. Bu da arabuluculuğun başarılı olmasinı engelleyebilir.

Önerilen çözümlerden bir tanesi de birisi arabulucu ve diğeri hakem olarak görev alacak iki kişinin birlikte arabuluculuk sürecini başlatmalarıdır. Müstakbel veya muhtemel hakem, arabulucuyla birlikte taraflar arasinda yapilan toplantılara katılmaktadır. Arabulucunun taraflarla yaptı̆̆ı birebir görüşmelere ise katılmamaktadır. Arabuluculuk süreci başarısız olursa hakem tahkim yargılamasını başlatacaktır. $\mathrm{Bu}$ yöntemin avantajı, hakemin taraflarla birebir görüşmelere katılmaması nedeniyle, gizli bilgilerin korunması ve hakemin tarafsılı̆̆ının etkilenmesi riskini bertaraf etmesidir. Bu yola getirilen eleştiri ise arabuluculuktan farklı olarak tarafların kendi istekleriyle görüşmelerden çekilme imkânına sahip olmamalarıdır ${ }^{103}$.

Bu yola getirilen bir diğer eleştiri ise arabuluculuk aşamasında taraflar arasında yapılan görüşmelerin (müstakbel) hakem önünde gerçekleşmesi nedeniyle tarafların davranış biçimlerinin bundan etkilenmesi veya hakemin tarafların arabuluculuk sürecindeki tutumları nedeniyle önyargılar geliştirebilmesidir. Bu yolun diğer zafiyeti ise arabulucu ve hakeme ücret ödeneceği için uyuşmazlığın çözümü maliyetinin artmasıdır ${ }^{104}$.

\footnotetext{
100 Weisman 41; Ibid 11; benzer şekilde bkz.: Stipanowıch, Yang, Welsh, Qiming, Robinson, Jinghui, Guang, Kichaven, Madigan, Hongsong, Jianhua 405.

101 Srikant and Arka 96.

102 Ibid 92.

103 Fullerton 36.

104 Ibid 35
} 
Diğer bir çözüm yolu ise arabuluculuk sürecinde arabulucunun her iki tarafın katıldığ 1 toplantılar yapması, taraflarca sunulan belgelerle yetinmesi ve taraflarla birebir görüşmeler yapmamasıdır. Ancak bu yönteme getirilen eleştiri ise taraflarla birebir yapılan görüşmelerin arabuluculuğun başarısına olan önemli etkisinin kaybedilecek olmasıdir ${ }^{105}$.

Önerilen başka bir çözüm ise, aynı kişinin önce arabulucu olarak görev yapması, sonra hakem olarak tahkim yargılamasına geçmesi ve tahkim devam ederken tarafları tekrar sulh müzakeresine davet etmesidir. Böylece, tarafların arabuluculuğun ruhuna uygun olarak yine kendi çözümlerini üretebilmeleri sağlanabilir. Bu yöntemin sakıncası ise hakemin tarafları müzakerelere davet etmesinin taraflar üzerinde baskı kurmasına neden olabilmesidir. Hakemin, tahkim aşamasında sunduğu çözüm önerisi varsa bu öneri taraflarca tavsiye olarak algılanabileceği gibi üstü kapalı bir talimat olarak da algılanabilir. Hakemin çözüm önerisinin taraflarca bir talimat olarak algılanması hâlinde arabuluculuğun tarafların kendi çözümlerini kendilerinin bulması özelliğini ortadan kaldırabiliır ${ }^{106}$.

Diğer bir öneri ise, arabuluculuk sürecinin başarısızlıkla sonuçlanması hâlinde taraflara tahkime devam etmekten çekilme imkânı tanınmasıdır. Böylece arabuluculuğun taraflardan birisi tarafından sonlandırılabilmesine ilişkin özelliği muhafaza edilebilir. Ancak bu durumda da Tahkim-Arabuluculuk Yolunun sağladığı uyuşmazlığın mutlaka nihai olarak çözümlenmesine ilişkin faydadan vazgeçilmiş olur ${ }^{107}$.

Arabuluculuk aşamasının taraflar üzerindeki yukarıda bahsettiğimiz zorlayıcı gücünü bertaraf etmek için tarafların verilecek hakem kararının da bağlayıcı olmadığı üzerinde anlaşmaları olduğu ifade edilmiş ancak bu hâlde uyuşmazlığın nihai olarak çözüme kavuşturulamaması riskine değinilmiştir ${ }^{108}$. Yukarıda açıkladığımız gibi ${ }^{109}$, tarafların hakem kararının bağlayıcı olmayacağına dair anlaşmaları, Türk hukukunda tereddüde yer vermeyecek kadar açık bir tahkim iradesi olmadığını gösterir, tahkim anlaşmasının geçersiz sayılmasına ve uyuşmazlığın Devlet yargısında çözümlemesine neden olabilir.

Başka bir yöntem ise Tahkim-Arabuluculuk Yolu olarak ifade edilebilir. Bu yöntemde, ilk önce tahkim yargılaması tamamlanmakta ve hakem bir karar vermektedir. Ancak kararı, taraflara tebliğ etmeden önce tarafları sulh görüşmelerine davet etmekte ve taraflar arasındaki görüşmeleri destekleyerek tarafların uyuşmazlıklarını sulhle sona erdirmelerini sağlamaya çalışmaktadır. Bu aşamada hakem taraflara, bu toplantılarında karar hakkında bilgi vermemeleri koşuluyla birebir görüşmeler yapabilir. Sulh gerçekleşirse hakem kararı taraflara açıklanmaz ve uyuşmazlık sulhen çözülmüş olur.

\footnotetext{
105 Baril and Dickey 4 ff; Sussman 71; Fullerton 35.

106 Fullerton 35.

107 Baril and Dickey 4 ff; Sussman 71; Ibid 36; Srikant and Arka 92 ff; Ibid 32.

108 Ildir 104.

109 Bkz. IV.A.
} 
Sulh gerçekleşmezse hakem kararı tebliğ edilir ve uyuşmazlık hakkında nihai bir karara verilmiş olur. Tahkim-Arabuluculuk Yolunun faydası tahkim yargılaması sırasında sunulan deliller, iddia ve savunmalar sonucunda tarafların kendi iddialarının güçlü ve zayıf tarafların daha iyi değerlendirebilmeleri ve bunun sulh ihtimalini artırmasıdır. Kararın zaten verilmiş olması nedeniyle taraflar karar yerine sulh olmaya daha istekli ve gayretli olacakladır. Diğer taraftan hakemin arabuluculuk sırasında edindiği gizli bilgeler nedeniyle tarafsızlıklarını kaybetmeleri ihtimali de bertaraf edilmiş olacaktır. Hakem ise kararını arabuluculuk süreci başlamadan vermiştir ve arabuluculuk sürecinde edindiği izlenime ya da öğrendiklerine göre kararını değiştiremez. Fakat bu yöntemin zayıf tarafı ise tarafların sulh olmak için üzerlerinde yoğun bir baskı hissetmeleridir ${ }^{110}$. $\mathrm{Bu}$ yöntemin diğer bir dezavantajı da, kanımızca, yargılama masraflarının artması ve uyuşmazlığın kısa sürede çözülemeyecek olmasıdır. Böylece, arabuluculuk ve tahkimin arka arkaya olmasından beklenen yargılama hızı ve maliyetlerinin düşük olabilmesi avantajları da gerçekleşmeyebilir.

Arabulucunun hakem olarak görev yapmasının yarattığı sakıncaların bertaraf edilebilmesinin arabulucunun niteliklerine bağlı olduğu ifade edilmektedir. Arabuluculuk-Tahkim Yoluna ilişkin yukarıda ifade ettiğimiz risklerin önemli bir kısmı arabulucu-hakemin işin niteliğine uygun davranamayacağı kaygısından kaynaklanmaktadır ${ }^{111}$. Arabulucu-hakem, hem arabuluculuk hem de tahkim alanında tecrübeli olmalıdır. Görev alacak kişi, arabuluculuğun ve tahkimin birbirinden farklı uyuşmazlık çözüm yöntemi olduklarının; arabulucunun ve hakemin rolünün iki aşamada birbirinden farklı olduğunun; arabulucunun ve hakemin taraflara karşı davranışlarının farklı olması gerektiğinin farkında olmalıdır. Arabuluculuk aşamasındaki tarafların müzakerelerini kolaylaştırma görevinden uyuşmazlık hakkında karar verme görevine geçebilmelidir. En önemlisi, arabuluculuk aşamasında öğrendiklerini hakem olarak görev yaparken bilmiyormuş gibi davranabilmelidir. Son olarak, arabulucu-hakem, arabuluculuk aşamasında tarafların güvenini kazanabilmeli ve bunu tahkimde de koruyabilmelidir ${ }^{112}$.

$\mathrm{Bu}$ değerlendirmeler sonucunda, yukarıda ifade ettiğimiz varyasyonların hiçbirisi hem tahkime hem de arabuluculuğa hâkim olan ilke ve avantajları bir arada koruyamamaktadır ve bu risklerin tamamını bertaraf eden bir çözüm yolu olmadığı da açıkça ifade edilmektedir ${ }^{113}$.

\section{Değerlendirme ve Sonuç}

Öncelikle, yukarıda açıkladığımız risklerin gündeme gelmesi için, arabuluculuk faaliyeti başlamış, arabulucu, görevi nedeniyle uyuşmazlık hakkında gizli bilgilere,

\footnotetext{
10 Fullerton 35.

111 Telford 7; Baril and Dickey 6.

112 Weisman 40; Ibid 7; Ibid 6; ayrıca bkz.: Sussman 73.

113 Fullerton 37; Baril and Dickey 6.
} 
tarafların sulh tekliflerine ve uyuşmazlık hakkındaki tutumlarına tanık olmuş olmalıdır. Kısaca, denenmiş ve başarısızlıkla sonuçlanmış bir arabuluculuk sürecine katılan bir arabulucunun tahkimde hakem olarak görev yapmasının yarattığı riskler söz konusudur. Buna karşılık, arabuluculuk faaliyeti hemen hemen hiç ilerlememiş hatta bir tanışma toplantısından ileriye gidememiş olabilir. Bu aşamada sona eren bir arabuluculuk faaliyetine arabulucu olarak iştirak eden kişinin hakem olmasının yukarıda açıkladığımız riskleri yaratmadığı kanaatindeyiz ${ }^{114}$.

Arabulucunun hakem olarak görev yapmasina yasal engel bir yoktur. Taraflar, Arabuluculuk-Tahkim Yolunun sağladığı avantajları ve riskleri bilerek ve iyi kavrayarak Arabuluculuk Tahkim Yolunu seçmişlerse seçimlerinin bu riskleri barındırdığının farkındadır ${ }^{115}$. Hatta arabulucunun hakem olarak görev yapmasının kabul edildiği hallerde arabuluculuk aşamasında öğrenilen bilgilerin tahkimde kullanmasına izin veren yazılı bir anlaşma da yapılabilir ${ }^{116}$.

Bu noktada Hukuk Uyuşmazlıklarında Arabuluculuk Kanununun 5inci maddesine dikkat çekmek uygun olur. 5inci madde uyarınca, arabuluculuk faaliyeti sırasında tarafların teklifleri; arabuluculuk faaliyeti esnasında, taraflarca ileri sürülen öneriler veya herhangi bir vakıa veya iddianın kabulü tahkimde delil olarak kullanılamaz. Sunulsa bile hakemler bu belge ve bilgileri kararlarında esas alamazlar. Oysa arabulucunun hakem olarak görev alması hâlinde tüm bunları bilen ve kuvvetle muhtemel hatırlayan kişi hakem sıfatıyla icrası kabil ve nihai bir karar verecektir. Dolaysıyla, arabulucunun hakem olması hâlinde 5inci maddeden beklenen fayda ortadan kalkabilir. Zira arabulucudan hakem olarak tarafsiz bir yargılama yapması için arabuluculuk faaliyeti sarasında öğrendiği ve kararını etkileyecek her şeyi unutmasını ve aynı meseleyi bu sefer bambaşka bir gözle ele almasını beklemek ağır bir beklentidir ve bu beklentinin karşılanması arabulucunun niteliklerine bağlıdır ${ }^{117}$.

Taraflar arabulucunun tarafsız hakem olabileceğine dair bilinç ve kaygılarına rağmen Arabuluculuk-Tahkim Yolunu seçmişlerse arabuluculuk aşamasında açı sözlü ve samimi bir arabuluculuk faaliyetinden ziyade müstakbel hakemi yargılamaya hazırlanmak için gayret gösterebilir. O zaman da arabuluculuk kendisinden beklenen faydayı sağlayamaz.

Sonuç olarak, arabulucunun hakem olarak görev yapması uyuşmazlığın çözüm maliyetlerini düşürebilse ve tahkim sürecini hızlandırabilse bile bu seçimin hem arabuluculuk sürecini hem de tahkim yargılamasını olumsuz etkileyebileceği unutulmamalıdır.

\footnotetext{
114 Krş.: Özbek 52 ff.

115 Fullerton 32.

116 Ildir 102.

117 Tanınmış bir Amerikalı arabulucu olan Martin Teplisky tarafından İmkânsız olduğu da ifade edilmişstir (naklen) Telford 3 ff.
} 


\section{B. Arabuluculuk Faaliyetindeki Beyan ve Belgelerin Tahkim Yargılamasında Delil Değeri}

Arabuluculuk faaliyeti sırasındaki beyanların, arabulucu ve diğer tarafla paylaşılan belgelerin tahkim yargilamasında kabul edilebilir bir delil olup olmayacakları, kanımızca, arabuluculuk faaliyetiyle akabindeki tahkim yargılaması arasındaki en önemli gerilim noktalarından birisidir ${ }^{118}$ ve arabulucu ile hakem olarak görev alacak kişilerin farklı olması hâlinde söz konusu olabilir.

Arabuluculuk faaliyetinin amacın1, arabuluculuğun HUAK.m2'de yer alan tanımından hareketle, bir uyuşmazlık baş göstermesi hâlinde uyuşmazlığın taraflarının birbirlerini anlamalarını ve bu suretle çözümlerini kendilerinin üretmesini sağlamak olarak anlıyoruz. Arabulucu, kimin hukuken haklı olduğuna ilişkin bir yargılama yapmaktan ziyade tarafların kendileri için doğru çözümü bulmalarını sağlamaya çalışılmaktadır. Taraflar, arabuluculuk aşamasında bir çözüm bulabilmek için yargılamada aleyhlerine kullanılabilecek belgeleri diğer tarafla paylaşabilmeli ve uyuşmazlığın çözümüne ilişkin tekliflerde bulunabilmelidir. Arabuluculuk faaliyetinin başarısızlıkla sonuçlanması hâlinde bu beyan ve belgelerin yargılamada, taraflar aleyhine delil oluşturması ihtimali özellikle milletlerarası ticari uyuşmazlıklarda tarafların arabuluculuğa başvurmalarını engelleyecek; engellemese bile tarafların arabuluculuk müzakereleri sırasında, ileride aleyhlerine delil teşkil edebilecek beyan ve belgeleri diğer tarafla paylaşmalarına engel olacaktır ${ }^{119} \mathrm{ki}$ bu durum arabuluculuk faaliyetinin başarı şansını azaltacaktır. HUAK.m5, bu sorunu ayrıntılı bir şekilde düzenlemiştir.

Kanun, 5. maddede, belgeleri iki ana kategoriye ayırmıştır. Bunlardan ilki, arabuluculuk faaliyeti sırasında ve arabuluculuk nedeniyle üretilen belgelerdir. İkinci kategori ise uyuşmazlıkla ilgili vakıaları ispata yarayan delillerdir.

\section{Arabuluculuk Faaliyeti Sırasında ve Arabuluculuk Nedeniyle Üretilen Belgeler}

\section{a. Delil Olarak Kullanılmasının Yasak Olması}

Kanun 5inci maddesinde bu nitelikteki belgelerin, tahkimde delil olarak ikame edilmesini açıkça yasaklamıştır. Bu belgeler şunlardır:

a) Taraflarca yapılan arabuluculuk daveti veya bir tarafin arabuluculuk faaliyetine katılma isteğine ilişkin belgeler,

b) Uyuşmazlığın arabuluculuk yolu ile sona erdirilmesi için taraflarca ileri sürülen görüşler ve teklifler,

\footnotetext{
1821 Mayıs 2008 tarihli Avrupa Parlamentosu ve Konseyi Yönergesi (2008/52/EC) m. 7: “Arabuluculuğun, gizliliğe uyulacak şekilde yapılmasının amaçlandı̆̆ı düşünüldüğ̈̈nde, üye devletler, taraflar aksini kararlaştırmadığı takdirde arabulucuların veya arabuluculuk sürecinin yönetimine katılan kişilerin, arabuluculuk sürecinde ortaya çıkan veya arabuluculuk süreciyle ilgili olan bilgiler hakkında, herhangi bir hukuk veya ceza davasında ya da tahkimde delil göstermeye zorlanamamasını sağlarlar." (bkz.: https://eur-lex.europa.eu/legal-content/EN/TXT/PDF/?uri=CELEX:32008L0052\&from=EN, Erişim Tarihi 24/11/2019)

119 Özbek 33 ff.
} 
c) Arabuluculuk faaliyeti esnasında, taraflarca ileri sürülen öneriler veya herhangi bir vakıa veya iddianın kabulü,

ç) Sadece arabuluculuk faaliyeti dolayısıyla hazırlanan belgeler.

Kanunun 5inci maddesi yasağın kapsamını oldukça geniş bir şekilde düzenlemiştir. Maddenin 3üncü fikrası, bu nitelikteki belgelerin, tahkim yargılaması sırasında ikamesi yanında ibrazının talep edilmesini de yasaklamışır.

Kanunun 5incimaddesinin 4üncüfikrası, herhangi bir arabuluculuk faaliyeti sırasında ve arabuluculuk nedeniyle üretilen belgelerin sadece o arabuluculuğu takip eden tahkimde kullanılmasını yasaklamakla yetinmemiştir. Bunun ötesinde, arabuluculuk faaliyeti sırasında ve arabuluculuk nedeniyle üretilen belgeler arabuluculuğun başarısız olması nedeniyle devam eden yargılama dışında herhangi bir hukuk davası ve tahkimde de delil olarak kullanılamaz. Bu hükümle, sadece arabuluculuk konusu uyuşmazlıkla ilgili ve o tarafların açtıkları davalar değil, tarafların başka davalarında hatta üçüncü kişilerin davalarında bu bilgi ve belgelerin kullanılması yasaklanmıştır.

Bu belgelerin davada kullanılmasına ilişkin yasağın istisnası, yine 5inci maddede düzenlenmiştir. Söz konusu bilgiler, bir kanun hükmü tarafından emredildiği veya arabuluculuk süreci sonunda varılan anlaşmanın uygulanması ve icrası için gerekli olduğu ölçüde açıklanabilir.

Uluslararası Barolar Birliği Milletlerarası Tahkim Anlaşmalarının Kaleme Alınmasına İlişkin Kılavuz'unda yer alan örnek çok aşamalı tahkim anlaşmasında, tarafların tahkim öncesi başvuracakları uyuşmazlık çözüm yöntemleri esnasındaki iletişimin, sulh görüşmeleri çerçevesinde yapılmış kabul edilmesi ve yetkili hukukun sulh görüşmelerinin gizliliğini temin için yapılan hukuki düzenlemeler çerçevesinde korunması gerektiğine ilişkin bir ifade bulunmaktadır ${ }^{120}$.

ISTAC Arabuluculuk-Tahkim Kuralları'nın 6inc1 maddesi, arabuluculuk sürecinde elde edilen bilgi ve belgelerin tahkim yargılanmasında kullanılamamasını düzenlemiştir. Sadece taraflar ve arabulucu değil üçüncü kişiler de 61ncı maddede düzenlenen yasağa tabidir. Böylece, arabulucunun, tarafların veya üçüncü kişilerin 6ıncı maddede sayılan belge ve bilgileri tahkimde kullanmaları yasaklanmıştır.

6ıncı maddede sayılan bilgi ve belgeler şunlardır:

1. Uyuşmazlığın arabuluculuk yolu ile sona erdirilmesi için taraflarca ileri sürülen görüşler ve teklifler;

2. Arabuluculuk faaliyeti esnasında, taraflarca ileri sürülen öneriler veya herhangi bir vakıa veya iddianın kabulü;

3. Arabulucunun çözüm önerisi;

4. Taraflardan herhangi birinin arabulucunun çözüm önerisini kabul ettiğini veya edebileceğini belirten beyanı;

5. Sadece arabuluculuk faaliyeti dolayısıyla hazırlanan belgeler.

120 https://www.ibanet.org/ENews_Archive/IBA_27October_2010_Arbitration_Clauses_Guidelines.aspx (Erişim Tarihi 28.09.2019) 
Bu belge ve bilgilerin tahkimde delil olarak kullanılması açıkça yasaklanmıştır. Hakemler de taraflardan bu belgeleri sunmasını istemeyeceklerdir. Aynı şekilde, taraflar birbirlerinden bu nitelikteki belgeleri ibraz etmelerini isteyemezler ve hakemler bu belgelerin belgeleri yedinde bulunduran tarafça ibrazını emredemez.

\section{b. Yasak Belgelerin Tahkimde Delil Olarak Sunulmasının Sonuçları}

Hukuk Uyuşmazlıklarında Arabuluculuk Kanunu'nun açikça yasaklamasına rağmen tarafların bu bilgi ve belgeleri tahkimde delil olarak sunmaları hâlinde dahi hakemler bu belge ve bilgelere dayanarak hüküm tesis edemezler (HUAK.m5(3)) ${ }^{121}$.

Yukarıda açıkladığımız belgelerin yasak olmasına rağmen tahkimde delil olarak kullanılmasının ya da kullanılmak istenmesinin sonuçları ISTAC ArabuluculukTahkim Kuralları'nın 6ıncı maddesinin ikinci fikrasında düzenlenmiştir. Buna göre, yasak belgeler delil olarak sunulmuş olsa bile hakemler bu belgeleri hükme esas alamaz. Görüldüğü gibi HUAK ve ISTAC Arabuluculuk-Tahkim Kuralları aynı düzenlemeye sahiptir.

ISTAC Kuralları'nda ${ }^{122}$, yasak belgelerin sunan taraf için bir yaptırım olarak yargılama giderlerine mahkûm edilmesi düzenlenmiştir. Buna göre, bir taraf bu yasak belgeleri delil olarak sunmuşsa diğer taraf hakemlerden belgeleri sunan tarafin yargılama giderlerine mahkûm edilmesini isteyebilir. Bu madde uyarınca, hakemlerin takdir yetkisi vardır ve mutlaka yargılama giderlerinin tamamının o tarafça ödenmesine karar vermek zorunda değildir. Kanımızca, hakemler yargılama giderlerinin kısmen o tarafça ödenmesine ya da talebin reddine de karar verebilirler. Maddede ifade edilen yargılama giderleri, belgelerin delil olarak kullanılmasının neden olduğu yargılama giderleriyle sınırlı değildir. Her türlü yargılama gideri bu madde kapsamındadır.

Hakemlerin bu hükme rağmen arabuluculuk faaliyeti sirasında ve arabuluculuk nedeniyle üretilen belgelere dayanarak hüküm tesis etmeleri, kararın icrasını tehlikeye atabilir. Zira arabuluculuk faaliyeti sırasinda ve arabuluculuk nedeniyle üretilen belgelere isnat edilerek verilen bir karar MTK'nın 15inci ve HMK'nın 439uncu maddelerinde sayılan hakem kararının iptali sebeplerinden biri hatta birden fazlası kapsamında iptal sebebi teşkil edebilir. Aynı şekilde, Yabancı Hakem Kararlarının Tanınması ve Tenfizine İlişkin 1958 tarihli New York Sözleşmesi ${ }^{123}$ 'nin V. maddesinde sayılan tenfizi engelleyici sebepler kapsamında yabancı bir hakem kararının Türkiye'de tenfizine engel olabilir.

\footnotetext{
121 HUAK.m5 (3) Birinci fikrada belirtilen bilgilerin açıklanması mahkeme, hakem veya herhangi bir idari makam tarafindan istenemez. Bu beyan veya belgeler, birinci fikrada öngörülenin aksine, delil olarak sunulmuş olsa dahi hükme esas alınamaz. (...)

122 "Birinci fikrada belirtilen bilgilerin açıklanması ve belgelerin sunulması hakem kurulu tarafindan istenemez. Bu bilgi ve belgeler, birinci fikrada öngörülenin aksine, delil olarak sunulmuş olsa dahi hükme esas alınamaz. Hakem kurulu, karșı tarafın talep etmesi üzerine, bu bilgi ve belgeleri sunan tarafı tahkim yargılamasının tüm giderlerini ödemeye mahkum edebilir."

123 Yabancı Hakem Kararlarının Tanınması ve İcrası Hakkındaki New York Sözleşmesi, Kabul Tarihi: 10.06.1958, RG 25.09.1991-21002
} 
Öncelikle, Hukuk Uyuşmazlıklarında Arabuluculuk Kanunu'nun 5inci maddesinin üçüncü fikrasının yeterince açık olmadığı kanaatindeyiz. Bu yöndeki görüşümüzü değişik ihtimallerle ele almak, sorunun daha iyi ortaya konulmasına katkı sağlayabilir.

Birinci ihtimalde, taraflardan birisi bu belgeleri yargilamada delil olarak ikame etmiş olabilir. Hakemler diğer tarafın itirazı üzerine veya re'sen bu belgelerin kabul edilebilir delil olmadığını belirtip deliller arasından çıkarılmasına karar verebilir (Milletlerarası Tahkimde Delilerin İbrazı Hakkında Uluslararası Barolar Birliği Kuralları.m9(2)). Hakemler belgenin kabul edilebilir bir delil olup olmadığına karar verirken belgeleri incelemeyerek belgenin içeriğine vâkıf olmayabilirler.

ISTAC Arabuluculuk -Tahkim Kuralları'nın 4üncü maddesinde kullanılmak istenilen delilin kullanılmasının 6ıncı madde uyarınca yasak olup olmadığına ilişkin bir uyuşmazlık çıkması hâlinde hakemlerin belgeyi incelemelerine ilişkin bir düzenleme yapılmıştır. Bu fikraya göre, "arabuluculuk sürecinde ortaya çıkan bir delilin tahkimde ileri sürülebilen bir delil olup olmadığ konusunda herhangi bir tereddüt veya taraflar arasında bir uyuşmazlık varsa, hakem kurulu ilgili delilin içeriğini incelemeden bu delilin kabul edilip edilemeyeceği konusunda karar verir. Hakem kurulunun delili incelemeden bu konuda karar verememesi durumunda, hakem kurulu, delilin kabul edilebilirliği konusunda bir bilirkişiyi beş işgünü içinde görüşünü sunmak üzere görevlendirebilir”.

Uygulamada, hakemler taraflarca dosyaya ibraz edilse bile sunulan delilin kabul edilebilir bir delil olduğunun şüpheli olması hâlinde bu delilleri, örneğin bir zarfın içine koymakta ve belgelerin delil durumları konusunda bir karara varılıncaya kadar belgeleri görmemektedir. Hakemler, bu belgelerin delil olarak kabul edilebilir olup olmadığına karar verebilmek için bile belgeleri incelemekten kaçınabilirler. Zira hakem bir kere içeriğini öğrendikten sonra kararında bu belgenin etkili olup olmadığına vicdanen tam bir kanaat getirmek mümkün olmayabilir. Bu nedenle, hakemler belgelerin delil niteliği konusunda karar verirken belgelerin içeriğini incelemesi ve içeriği hakkında değil ama niteliği hakkında hakemler için bir rapor hazırlamaları için re'sen bilirkişi atayabilirler (Milletlerarası Tahkimde Delilerin İbrazı Hakkında Uluslararası Barolar Birliği Kuralları.m9(4)). Görüldüğü gibi birinci ihtimalde, hakemlerin delil olarak kullanılması HUAK.m5(3) tarafindan yasaklanan belgeleri hiç görmedikleri ve karar verirlerken bu belgelerden etkilenmeyecekleri düşünülebilir.

İkinci ihtimalde ise hakemler bu yasak delilleri incelerler ancak hakem kararında bu belgelere dayanmazlar. Hakem kararı okunduğunda bu yasak delillerin tahkim yargılamasında delil olarak kullanıldıkları anlaşılamaz. Hukuk Uyuşmazlıklarında Arabuluculuk Kanunu'nun 5inci maddesinin lafzına bakılırsa hakem kararında esas alınmadığ1 sürece bu belgelerin delil olarak sunulmasının kararın sıhhatine ilişkin bir sonucu yoktur. Bu belgelerin sunulduğu hâllerde hakem kararından bu belgelere 
dayanılarak karar verildiği anlaşılmadığı sürece hakemler 5inci maddeye uygun davranmış olurlar.

Üçüncü ihtimalde ise arabuluculuk faaliyeti sırasında ve arabuluculuk nedeniyle üretilen belgeler delil olarak kullanılmış ve hakemler de bu belgeleri delil olarak değerlendirip kararlarını bu belgelere dayandırmışlardır. Kanunun 5inci maddesi bu ihtimali açıkça yasaklamıştır.

Kanunun 5inci maddesi, arabuluculuk faaliyeti sırasında ve arabuluculuk nedeniyle üretilen belgelere erişim imkânına kavuşan hakemlerin bu belgelerin içeriğinden etkilenmelerine rağmen herhangi bir yerde bu etkinin izine rastlanmaması ihtimalini göz ardı etmektedir. Özellikle hakemlerin heyet olarak görev yaptı̆̆1 hallerde bazı heyet üyeleri bu belgeleri incelemiş ve içeriğinden etkilenmiş olabilir, ancak diğer üyeler belgeleri incelemedikleri gibi hakemlerinden birisinin bu belgeleri incelediğinden de habersiz olabilir.

Kanunun 5inci maddesinin üçüncü fikrasının zafiyeti, hakemlerin vardığı sonuç ile arabuluculuk faaliyeti sırasında ve arabuluculuk nedeniyle üretilen belgelerin içeriğine vakıf olmaları arasındaki illiyet bağının, diğer bir ifadeyle hakemlerin bu belgeleri kararlarına esas aldıklarını ispatlanmasının çok zor olmasıdır. Hakemler, örneğin, davacı arabuluculuk faaliyeti sırasında kendisine bu davadaki talebinin yarısının ödenmesini teklif etmiştir o halde talebinin yarısına hükmedilmelidir şeklinde açıkça belirterek karar vermişlerse belgenin karara esas alındığı açıkça görülebilir. Ama hakemler bunu demek yerine, talep sonucunun sadece \% 54'ünün davacı tarafından üçüncü kişilere ödendiğine ilişkin ıslak imzalı belge olduğunu geri kalan \% 46'nın ödendiğine ilişkin belgelerin ıslak imzalı olmaması nedeniyle talebin sadece \% 54'ünü kabul ettiklerini belirtmişlerse ve talep edilen meblağın tamamının ödendiğini ispatlayan diğer delilleri göz ardı etmişlerse hakemlerin arabuluculuk faaliyeti sırasında ve arabuluculuk nedeniyle üretilen belgeleri kararlarına esas almadıklarından emin olabilir miyiz, farklı bir ifadeyle, kararın iptalini sağlamak için karara esas alındı̆̆

Yasak belgelerin karara esas alındığının ispatlanabilmesi hâlinde hakem kararının iptal edilip edilmeyeceği veya tenfizinin reddedilip edilemeyeceği aşağıda incelenecektir.

\section{i. Kararın Lex Arbitri'nin Emredici Kanunlarının İhlal Edilerek Verilmesi}

MTK'nın 8inci maddesi uyarınca, hakemler MTK'nın emredici hükümlerine uygun bir tahkim yargılaması yürütmek zorundadır. Öncelikle, Hukuki Uyuşmazlıklarda Arabulucluk Kanunu'nun 5inci maddesi, Türkiye'nin tahkim yeri olduğu tahkimlerde, tahkim yargılamasında delillerin kabul edilebilirliğini düzenleyen emredici bir usul hukuku hükmü olduğu kanaatindeyiz. Bu itibarla 5inci madde lex arbitri'nin 
emredici milli ve milletlerarası tahkim kurallarından birisidir. Bu hükmün MTK'da yer almaması hükmün MTK'nın 8inci maddesinin kapsamında emredici bir hüküm olmadığı anlamına gelmez.

İptal başvurusunu yapan taraf, tahkim yargılamasının, usul açısından tarafların anlaşmalarına veya bu yönde bir anlaşma bulunmaması hâlinde, Milletlerarası Tahkim Kanunu hükümlerine uygun olarak yürütülmediğini ve bu durumun kararın esasına etkili olduğunu ispat ederse hakem kararı iptal edilebilir (MTKm.15(A)(1) (f)). MTK'nın bu hükümlerinden hareketle, Hukuki Uyuşmazlıklarda Arabulucluk Kanunu'nun 5inci maddesi aykırı şekilde arabuluculuk faaliyeti sırasında ve arabuluculuk nedeniyle üretilen belgelere dayanan ve bu durumun hakem kararının esasına etkili olduğu ispatlanabilen hakem kararları tahkime uygulanan emredici usul hükümlerine aykırı bir karar olarak nitelenebilir ve iptal edilmeleri gündeme gelebilir.

Türkiye'nin taraf olduğu ve yabancı hakem kararlarının Türkiye'de tenfizini düzenleyen Hakem Kararlarının Tenfizi ve Tanınmasına İlişkin 1958 tarihli New York Sözleşmesi'nin tenfiz engellerini düzenleyen V(d) hükmü uyarınca, hakem kararı, tarafların uygulanmaları konusunda anlaştıkları, böyle bir anlaşma yoksa tahkim yerinin tahkime ilişkin usul kuralları ihlal edilerek verilmişse hakem kararının tenfizi reddedilebilir. Böylece, tahkim yerinin Türkiye olmadığı hallerde, hakem kararı, tahkim yerindeki Hukuki Uyuşmazlıklarda Arabulucluk Kanunu'nun 5inci maddesine benzer bir hüküm ihlal edilerek verilmişse hakem kararının tenfizinin reddi gerekebilir.

Ancak usul kuralı ihlalinin kararın iptaline neden ya da tenfizine engel olabilmesi için yapılan usul ihlalinin kararın esasına etkili olması gerekir ve bunun ispat yükü de iptali talep eden veya tenfize itiraz eden tarafa ait kabul edilebilir. Ancak buradaki ispat zorluğuna da dikkati çekmek uygun olur.

\section{ii. Kararın Kamu Düzenine Aykırı Olması}

Arabuluculuk faaliyeti sirasinda ve arabuluculuk nedeniyle üretilen belgelerin tahkim yargılamasında delil olarak kullanılması hâlinde verilen karar, Türk kamu düzenine aykırı olarak mütalaa edilebilir mi? Türk kamu düzenine aykırı olan hakem kararları iptal edilebilir (MTK.m15(A)(2)(b)) ve yabanc1 hakem kararlarının tenfizi reddedilebilir (New York Sözleşmesi.mV(2)(b)).

Arabuluculuk faaliyeti sirasında ve arabuluculuk nedeniyle üretilen belgelerin tahkimde delil olarak sunulmaları ve hakemlerin de bu belgeleri yargılama dışında tutmadan verdikleri kararlar Türk kamu düzenine aykırı mıdır sorusunun evet ya da hayır şeklinde verebileceğimiz soyut bir cevabı olmadığını düşünüyoruz.

HMK'nın 188inci maddesinin üçüncü fikrası uyarınca, sulh görüşmeleri sırasında yapılan ikrar, tarafları bağlamaz. Hukuki Uyuşmazlıklarda Arabulucluk Kanunu'nun 5inci maddesi de aynı ilkenin arabuluculuk faaliyetleri kapsamındaki görünümü 
olarak mütalaa edilebilir. Milletlerarası Tahkimde Delillerin İkamesine İlişin Uluslararası Barolar Birliği Kuralları'nın 9uncu maddesi de sulh görüşmeleriyle ilgili olarak ve uyuşmazlığın sulh yoluyla çözümlenmesi amacıyla meydana getirilen belgelerin, yazılı ve sözlü beyanların gizli tutulması gerektiğine ilişkin yasal düzenlemelerin bu sayılanların tahkimde delil olarak kabul edilmelerini engelleyeceğini düzenlemektedir. Görüldüğü gibi sulh görüşmelerinin yargılamadan gizli tutulması temin edilmek istenmektedir.

Taraflar, sulh müzakereleri sırasında meydana getirilen belgelerin ve beyanların tahkimde delil olarak kullanılabilecekleri konusunda anlaşabilirler. Nitekim Milletlerarası Tahkimde Delillerin İkamesine İlişin Uluslararası Barolar Birliği Kuralları'nın 9(3) maddesi de sulh görüşmelerinin bir parçası olması hasebiyle delil olarak kullanılması yasak belge ve beyanların istifade ettikleri yasal korumadan tarafların feragat etmelerinin mümkün olduğuna ve tarafların bu belge ve beyanları tahkim yargılamasinda delil olarak kullanarak yasal korumadan feragat etmeleri hâlinde bu belge ve beyanların tahkimde kabul edilebilir delil olarak mütalaa edilmelerine izin vermektedir. O halde, gerek HMK'nun 188inci maddesi gerek Hukuki Uyuşmazlıklarda Arabulucluk Kanunu'nun 5inci maddesi marifetiyle delil olarak kullanılmaktan korunan belge ve beyanlara sağlanan bu korumadan tarafların kısmen ya da tamamen feragat etmeleri mümkündür. Kisaca, bu belge ve beyanların sahibi olan taraflar bu belgelerden delil olarak yararlanırsa ve diğer taraf da buna itiraz etmezse bu belgeler tahkimde delil olarak kullanılabilirler. Hukuki Uyuşmazlıklarda Arabulucluk Kanunu'nun 5inci maddesinin aksine anlaşmaların geçerli olduğu dikkate alındığında hakem kararının 5inci maddeye aykırı olmasının, kararın kamu düzenine aykırı sayılması için tek başına yeterli olup olmadı̆̆ı tartışılmalıdır.

$\mathrm{Bu}$ konu esas itibariyle, arabulucunun tahkim aşamasında hakem olarak görev yapmasına ilişkin anlaşmaların tarafların arabuluculuk aşamasında ortaya çıkan gizli bilgilerin tahkimde kullanılmasına feragat ettikleri anlamına gelip gelmeyeceği düzleminde tartışılmıştır.

Arabulucunun önce arabulucu sonra hakem olarak görev yapmasının yarattığ1 en önemli kaygılardan bir tanesi, arabuluculuk aşamasında edinilen ve tahkim aşamasında taraflarca dile getirilmeyen bilgilerin hakem kararını etkilemesi ihtimalidir ${ }^{124}$. Karşılaştırmalı hukukta hakem kararlarının bu nedenle iptal edildiği vakidir.

ABD Ohio Mahkemesi tarafindan verilen Bowden v. Weickert ${ }^{125}$ kararında arabuluculuk aşamasında arabulucuya iletilen bilgilerin tahkim aşamasında kullanılmasının hakemlerin yetkilerini aşmış olmaları nedeniyle iptal sebebi olup olmadığı tartışılmıştır. Mahkeme kararında, arabulucu-hakemin tarafsız davranması

\footnotetext{
124 Bkz.: yuk. V.A.3. b.

125 Bowden v. Weickert (2003) Ohio 3223
} 
ve arabuluculuk aşamasında ortaya çıan gizli bilgileri koruması gerektiği belirtilmiştir. Arabulucu-hakem, kararına sadece tahkim aşamasında sunulan delilleri ve beyanları esas alabilir. Aksi halde hakem yetkisini aşmış olur. Bu durumda, taraflar arabuluculuk aşamasındaki beyanlarının tahkimde esas alınmamasından feragat etmedikçe bu bilgilere dayanan hakem kararı iptal edilmelidir ${ }^{126}$.

Massachusetts mahkemesi tarafindan verilen Town of Clinton v. Geological Services Corp. ${ }^{127}$ kararında, arabuluculuk aşamasında edinilen bilgilerin tahkimde kullanılmasına açıkça muvafakat edilmesi sadece arabuluculuk yoluna başvurulmasının bu süreçte edinilen bilgilerin tahkimde kullanılmasına zımnen de olsa muvafakat edildiği anlamına gelmeyeceği ifade edilmiştir ${ }^{128}$.

ABD mahkemeleri tarafindan verilen U.S. Steel Mining Company v. Wilson Downhole Services ${ }^{129}$ kararında ise tarafların arabuluculuk esnasında diğerinin yokluğunda hakeme sunduğu bilgilerin hakemin kararına esas alınması konusunda taraflar arasındaki anlaşmayı dikkate alarak gizli bilgilerin kararda kullanılmasının iptal sebebi olmayacağı belirtilmiştir ${ }^{130}$.

Hong Kong İstinaf mahkemesi, Gao Haiyan \& Another v. Keeney Holding Ltd \& Others $^{131}$ kararında, tarafların arabulucunun ileride hakem olarak görev yapmas1 üzerinde anlaşmaları hâlinde arabulucu-hakemin tarafsız olmadığı gerekçesiyle hakemi reddetmek haklarından feragat ettikleri sonucuna varmıştı1 ${ }^{132}$.

Logan v. $\operatorname{Logan}^{133}$ kararında da, hakem kararı, arabuluculuk aşamasında öğrenilen gizli bilgilere istinaden verilmişse ve bu bilgilere dayanılması taraflardan birisinin haklarını önemli ölçüde ihlal ediyorsa hakem kararının iptal edilebileceği sonucuna ulaşılmıştır. Ancak mahkeme arabuluculuk aşamasında edinilen bilgilerin ilgili tarafın hakkını esaslı bir şekilde ihlal edildiğinin ispatlanamaması nedeniyle hakem kararını iptal etmemiştir ${ }^{134}$.

Arabulucunun hakem olarak görev yapması nedeniyle verilen kararın tarafsız bir hakem kararı olmadığının ispat ölçüsü de tartışmalı konulardan birisidir. İngiltere ve Hong Kong mahkemeleri, hakemin tarafsız olmamasının gerçek bir risk olduğunun ispatlanması gerektiğini ifade etmişlerdir. Diğer bir yaklaşım ise tarafsızlığa ilişkin makul bir şüphenin kararın iptal edilmesi için yeterli kabul edilmesidir. Makul bir

\footnotetext{
126 Sussman 71; Srikant and Arka 89.

127 Town of Clinton v. Geological Servs. Corp. (2006) 21 Mass. L. Rep. 609

128 Srikant and Arka $89 \mathrm{ff}$.

129 U.S. Steel Mining Company v. Wilson Downhole Services (2006) 02:00CV1758 WL2869535

130 Sussman 72.

131 Gao Haiyan and another v. Keeneye Holdings and another (2011) CACV 79

132 Srikant and Arka $80 \mathrm{ff}$.

133 Logan v. Logan (2007) F051606 WL 2994640

134 Sussman 72.
} 
şüphe (vakıaları bilen üçüncü bir kişinin şüphe duyması), gerçek riskten daha kolay ispat edilebilir. İngiliz mahkemeleri, gerçek bir riskin varlığı hâlinde hakemin tarafsız olmadığı yönünde kararlar vermiştir. Hong Kong mahkemelerinin ilk kararları İngiliz mahkemelerinin yaklaşımıyla aynı olmuştur. Ancak müteakip kararlarda makul bir şüphenin varlığını yeterli görmüşlerdir. Singapur ve Hong Kong mahkemeleri ile aynı yaklaşımı benimsemiştir ${ }^{135}$.

Kararlardan görüldüğü gibi, Arabuluculuk Tahkim Yolunun kararlaştırıldı̆̆ 1 ve arabulucunun hakem olarak görev yapması konusunda tarafların anlaştıkları hallerde bu anlaşmanın gizli bilgilerin tahkimde kullanılmasından feragat edildiği anlamına gelip gelmeyeceği tartışılmıştır. Bu tartışma, verilecek cevap ne olursa olsun tarafların arabuluculuk aşamasındaki gizli bilgilerin tahkimde kullanılmasına muvafakat etmelerinin hukuken geçerli kabul edilmesi gerektiğini göstermektedir. $\mathrm{Bu}$ durumda, gizli bilgilerin hakem kararına esas alınması riskinin varlığının hakem kararının kamu düzenine aykırılık nedeniyle iptal edilmesi için tek başına yeterli olmayacağını söyleyebiliriz.

\section{Uyuşmazlıkla İlgili Vakıaları İspata Yarayan Deliller}

İkinci kategori olarak nitelediğimiz belgeler, arabuluculuk faaliyeti sırasında ve arabuluculuk nedeniyle üretilen belgeler değillerdir. Bunlar, vakıalara ilişkin belgelerdir. Örneğin, taraflar arasındaki sözleşmeler, yazışmalar, faturalar gibi iddia edilen vakıaların ispatına hizmet eden ispat araçlarıdır.

Hukuk Uyuşmazlıklarında Arabuluculuk Kanunu'nun 5inci maddesi uyarınca iddiaları ispat etmeye yarayan belgeler hem arabuluculuk faaliyeti hem de tahkim yargılaması sırasında kullanılabilir. Bu delillerin arabuluculuk sırasinda kullanılması, yargılamada delil olarak kullanılmasına engel değildir. ${ }^{136} \mathrm{Bu}$ madde kısaca, tarafların iddia ve savunmalarının temelini teşkil eden vakıaları ispata yarayacak belgelerin hem arabuluculukta hem tahkimde delil olarak kullanılabileceğini düzenlemektedir.

ISTAC Arabuluculuk-Tahkim Kuralları'nın 61ncı maddesinin 3üncü fikrası burada ikinci kategori olarak ifade edilen bilgi ve belgelerin tahkimde delil olarak kullanılmasına ilişkindir. Bu fikra uyarınca, 6ıncı maddenin birinci fikrası kapsamında olmayan belgeler, arabuluculuk aşamasında sunulmuş olsalar da tahkim aşamasında kabul edilebilir delil niteliğindedir.

\section{Arabulucunun Tahkimde Tanık Olması}

Yukarıdaki iki başlıkta, arabuluculuk faaliyeti çerçevesindeki müzakerelerde kullanılan belgelerin müteakip tahkimde delil olarak kullanılmasının mümkün olup

135 Srikant and Arka 90.

136 Çiğdem Yazıcı Tıktık, ‘Arabuluculukta Gizliliğin Korunması' (Doktora Tezi, İstanbul Kültür Üniversitesi 2010) 216. 
olmadığını tartışmaya çalıştık. Arabulucunun tahkimde hakem olması konusunu ise daha üst başlıkta ele almıştık. Bu başlık altında, arabulucunun müteakip tahkimde tanık olarak ifade vermesine değinilecektir.

Arabulucu müteakip tahkimde tanık olabilir mi sorusuna arabulucunun hangi konuda tanıklık edeceğine göre farklı cevap vermek uygun olabilir.

Arabulucu, arabuluculuk faaliyetiyle ilgili ve bu faaliyet sırasında öğrendikleriyle ilgili olarak tanıklık yapamaz. Hukuki Uyuşmazlıklarda Arabuluculuk Kanunu'nun 5inci maddesi açıkça arabulucunun tanıklık yapmasını yasaklamıştır

Arabulucu, arabuluculuk vazifesi dışında uyuşmazlıkla ilgili vakıalara da tanık olmuşsa sadece bunlarla sınırlı olarak tanıklık yapmasında bir engel olmadığını düşünüyoruz. Örneğin, arabulucu ayıplı olduğu iddia edilen imalatları yerinde incelemiş ancak bu imalatlar toprak altında kaldıkları için hakemin bunları bizzat inceleme imkânı yoksa arabulucu bu imalatlar hakkında gördükleri konusunda tanık ifadesi verebilmelidir. Arabulucu, bu vakıaları bağımsız ve tarafsız olarak gözlemiştir. Kişisel kanaatini katmadan sadece gördüklerini tanık olarak anlatmasına bir engel olmadığı kanaatindeyiz.

ISTAC Arabuluculuk-Tahkim Kuralları'nın 61nc1 maddesinin birinci fikrası tanıklığ1 arabuluculuk aşamasındaki bilgi ve belgeler hakkından tanıklığ 1 düzenlemektedir. Buna göre taraflar, arabulucu veya arabuluculuğa katılanlar da dahil üçüncü bir kişi, uyuşmazlıkla ilgili olarak tahkim yoluna başvurulduğunda maddede sayılan belgeler hakkında ${ }^{137}$ tanıklık yapamaz. Böylece arabulucunun tahkimde tanıklık yapması yasaklanmamış, sadece tanıklığın kapsamın daraltılmıştır. Sadece arabulucunun değil, tarafların ve üçüncü kişilerin de kullanılması yasak olan belgeler hakkında tanıklık yapması yasaklanmıştır.

\section{Sonuç}

Yukarıdaki tartışmalarımız sonucunda ulaştığımız tespitlerimizi şu şekilde s1ralayabiliriz:

Uyuşmazlık çözüm anlaşmasında tahkim davasına başlamadan önce tarafların arabulucuya başvurmaları ve arabuluculuk faaliyetinin başarısızlıkla sonuçlanması hâlinde tahkimde dava açılabileceğine ilişkin bir ön şart ancak kendi menfaatlerini doğru değerlendirebilmek için üçüncü bir kişinin (arabulucunun) yol göstermesine ihtiyaç duyabilecek taraflar arasında tahkime başvurmadan uyuşmazlığın çözülmesinde etkili olabilir. Menfaatlerini doğru değerlendiren taraflar tahkime başvurma kararı

\footnotetext{
137 Bu belge ve bilgiler şunlardır:

a) Taraflarca yapılan arabuluculuk daveti veya bir tarafın arabuluculuk faaliyetine katılma isteğine ilişkin belgeler,

b) Uyuşmazlığın arabuluculuk yolu ile sona erdirilmesi için taraflarca ileri sürülen görüşler ve teklifler,

c) Arabuluculuk faaliyeti esnasında, taraflarca ileri sürülen öneriler veya herhangi bir vakıa veya iddianın kabulü,

ç) Sadece arabuluculuk faaliyeti dolayısıyla hazırlanan belgeler.
} 
aldıklarında uyuşmazlığın sulhen çözüleceğine dair bütün umutlarını genellikle kaybetmiş olurlar ve uyuşmazlık öncesi alternatif çözüm yollarının öngörülmesi yargılamanın uzamasına ve yargılama masraflarının artmasına neden olabilir.

Çok basamaklı tahkim anlaşmasına rağmen tahkim yargılamasının önceki aşama tüketilmeden başlatılması hâlinde hakemler çok basamaklı tahkim anlaşmasını yorumlamalıdır. Hakemler, arabuluculuk aşamasının tüketilmiş olmasını tahkim anlaşmasının hüküm ve sonuç doğurmasının bir ön şartı olduğuna kanaat getirirlerse tarafların arabulucuya başvurmaları için tahkim yargılamasının durdurulmasına karar vermeleri ve uyuşmazlık arabuluculuk aşamasında sulhen çözümlenemezse yargılamanın devam etmesi uyuşmazlığın daha hızlı ve az maliyetle çözülmesine hizmet eder.

Arabulucu olarak görev yapan kişinin tahkimde hakem olarak görev yapmasının faydaları yanında önemli riskleri de vardır. Uluslararası etik kuraları ve Türkiye'deki etik kuralları, hakemin arabulucu olarak görev yapmasının hakemin tarafsızlığını objektif olarak şüpheli hâle getirdiğini kabul etmişler ve arabulucunun ancak tarafların anlaşması hâlinde hakem olarak görev yapmasına izin vermişlerdir. Tarafların bu konudaki rızaları, arabulucunun hakem olarak görev yapmasının riskleri konusunda bilgili ve bilinçli olmalarını gerektirir.

Arabuluculuk faaliyeti sirasında ve arabuluculuk nedeniyle üretilen belgelerin tahkimde delil olarak sunulması ve hakemlerin bu bilgi ve belgelere dayanarak hakem kararını vermiş olması hakem kararının iptaline veya tenfizine engel olabilir.

2019 yılının Kasım ayında yayınlanarak yürürlüğe giren İstanbul Tahkim Merkezi Arabuluculuk - Tahkim Kuralları uygulamanın beklentilerini karşılamak üzere hazırlanmış ve Arabuluculuk-Tahkim kurumunun gelişmesine katkı sağlayacak olması nedeniyle ülkemizde alternatif uyuşmazlık çözüm yöntemlerinin gelişmesine büyük bir katkı sağlayacaktır.

Finansal Destek: Yazar bu çalışma için finansal destek almamıştır. 


\section{Bibliyografya/Bibliography}

Akıncı Z, Milletlerarası Tahkim (4th, Vedat 2016).

Baril MB and Dickey D, 'MED-ARB: The Best of Both Worlds or Just A Limited ADR Option' 1 (https://www.semanticscholar.org/paper/MED-ARB-\%3A-The-Best of-Both-Worlds-or-JustA-Limited-/79ffef5650e52059b27d320bd6b1d0081232822d, Erişim Tarihi 09/09/2019)

Berkhan İ, Tahkim ve Arabuluculukta Tarafslzlık Ilkesi, (1st, Aristo 2019)

Boog C, 'How to Deal with Multi-tiered Dispute Resolution Clauses - Note - 6 June 2007 - Swiss Federal Supreme Court' 26(1) 2008 ASA Bulletin 111-112

Born G, International Commercial Arbitration "Formation, Validity and Legality of International Arbitration Agreements" (2nd Wolters Kluwer Law \& Business 2014)

Bozkurt SB, Milletleri Ticari Tahkimde Hakemlerin Bağımsızlık Yükümlülüğü (1st On İki Levha 2016)

Brian AP, 'Med-Arb and the Legalisation of Alternative Dispute Resolution' 2015 20(157) Harv. Negot. L. Rev. 157-203.

Cheng T, 'Reflections on Culture in Med-Arb' 2010 34(9-10) NYLS Legal Studies (SSRN: https:// ssrn.com/abstract=1574814 or http://dx.doi.org/10.2139/ssrn.1574814, Erişim Tarihi: 11/09/2019).

Ekşi N, Tahkim Öncesi Uyuşmazlık Çözüm Usulleri ve Bu Usuller Tüketilmeden Tahkime Başvurulmasının Sonuçları ( 1st, Beta 2015).

Ersen Perçin G, 'Alternatif Uyuşmazlık Çözüm Yöntemlerinden Arabuluculuğun Hukuksal Düzenlemelerdeki Yeri’ 2011 31(2) Public and Private International Law Bulletin 177-201.

Fullerton R'The Ethics of Mediation - Arbitration’ 2009 38(5) The Colorado Lawyer 31-38.

Ildır G, Alternatif Uyuşmazlık Çözümü (1st, Seçkin 2003)

Kekeç EK, Arabuluculuk Yoluyla Uyuşmazlık Çözümünde Temel Aşamalar ve Taktikler (1st Adalet 2011)

Özbek MS, 'Arabuluculuk ile Tahkim Yöntemlerinin Kesişme Bölgesi: Arabuluculuk-Tahkim' 2017 43(1) Yargitay Dergisi 15-106.

Öztürk N, ‘Arabuluculuğun Milletlerarası Özel Hukuk Boyutu: Genel Bakış’ 2015 31(2) Batıder 203-256.

Russel F, Russel on Arbitration ( 24th edn, Sweet \& Maxwell 2015)

Sussman E, Edna Sussman, 'Developing an Effective Med-Arb/Arb-Med Process' 2009 2(1) NYSBA New York Dispute Resolution Lawyer

Srikant D and Arka S, Amalgamating The Conciliatory And The Adjudicative: Hybrid Processes And Asian Arbitral Institutions' 2014 III(1) Indian Journal of Arbitration Law 76-100.

Şanlı C, Uluslararası Ticari Akitlerin Hazırlanması ve Uyuşmazlıkların Çözüm Yolları, İstanbul 2016.

Şanli C, Esen E and Ataman Figanmeşe İ, Milletlerarası Özel Hukuk, İstanbul 2018.

Tan Dehmen M, “Tahkim Öncesi Müzakere ya da Uzlaştırma Yollarının Tüketilmemiş Olmasının Tahkim Yargilamasına Etkisi” (2011) 25(1-2) MHB 451-472.

Taşpolat Tuğsavul M, Arabuluculuk Kanunu Çerçevesinde Türk Hukukunda Arabuluculuk (Yüksek Lisans Tezi), İstanbul, 2009.

Telford M E, Med-arb: a viable dispute resolution alternative (1st IRC 2000),

Stipanowich TJ, Yang, Welsh J, Qiming C, Robinson P, Jinghui T, Guang C, Kichaven J, Madigan 
D, Hongsong W and Jianhua Z, 'East Meets West: An International Dialogue on Mediation and Med-Arb in the United States and China' 2009 2(9) Pepp. Disp.Resol. L.J. 384 (https:// digitalcommons.pepperdine.edu/drlj/vol9/iss2/5 Erişimi Tarihi 3/09/2019)

Weisman MC, 'Med -Arb: The Best of Both Worlds' 2013 19(40) Dispute Resolution Magazine 40-41.

Yarar G, Milletlerarası Özel Hukukta Arabuluculuk (1st, On İki Levha 2019)

Yazıcı Tıktık Ç, Arabuluculukta Gizliliğin Korunması' (Doktora Tezi, İstanbul Kültür Üniversitesi 2010).

Yeşilirmak A, Türkiye'de Ticari Hayatın ve Yatırım Ortamının İyileştirilmesi İçin Uyuşmazlıkların Etkin Çözümünde Doğrudan Görüşme, Arabuluculuk, Hakem-Bilirkişilik ve Tahkim: Sorunlar ve Çözüm Önerileri (1st, On İki Levha 2011) 